\title{
CABIN AIR QUALITY ON NON-SMOKING COMMERCIAL FLIGHTS: A REVIEW OF PUBLISHED DATA ON AIRBORNE POLLUTANTS
}

\author{
Ruiqing Chen ${ }^{1}$, Lei Fang ${ }^{2}$, Junjie Liu ${ }^{1}$, Britta Herbig ${ }^{3}$, Victor Norrefeldt ${ }^{4}$, Florian Mayer ${ }^{4}$, \\ Richard Fox ${ }^{5}$ and Pawel Wargocki ${ }^{2 *}$
}

1 Tianjin Key Laboratory of Indoor Air Environmental Quality Control, School of Environmental Science and Engineering, Tianjin University, China

2 International Centre for Indoor Environment and Energy, Department of Civil Engineering, Technical University of Denmark

3 LMU University Hospital Munich, Institute and Clinic for Occupational, Social and Environmental Medicine, Germany

4 Fraunhofer Institute for Building Physics IBP, Holzkirchen Branch, Germany

5 Aircraft Environment Solutions Inc., USA

* Corresponding author: email paw@byg.dtu.dk

\begin{abstract}
We reviewed 47 documents published 1967-2019 that reported measurements of volatile organic compounds (VOCs) on commercial aircraft. We compared the measurements with the air quality standards and guidelines for aircraft cabins and in some cases buildings. Average levels of VOCs for which limits exist were lower than the permissible levels except for benzene with average concentration at $5.9 \pm 5.5 \mu \mathrm{g} / \mathrm{m}^{3}$. Toluene, benzene, ethylbenzene, formaldehyde, acetaldehyde, limonene, nonanal, hexanal, decanal, octanal, acetic acid, acetone, ethanol, butanal, acrolein, isoprene and menthol were the most frequently appearing compounds. The concentrations of SVOCs (Semi-Volatile Organic Compounds) and other contaminants did not exceed standards and guidelines in buildings except for the average $\mathrm{NO}_{2}$ concentration at 12 ppb. Although the focus was on VOCs, we also retrieved the data on other parameters characterizing cabin environment. Ozone concentration averaged $38 \pm 30$ ppb below the upper limit recommended for aircraft. The outdoor air supply rate ranged from 1.7 to $39.5 \mathrm{~L} / \mathrm{s}$ per person and averaged $6.0 \pm 0.8 \mathrm{~L} / \mathrm{s} / \mathrm{p}$ (median $5.8 \mathrm{~L} / \mathrm{s} / \mathrm{p}$ ), higher than the minimum level recommended for commercial aircraft. Carbon dioxide concentration averaged 1,315 $232 \mathrm{ppm}$,
\end{abstract}


lower than what is permitted in aircraft and close to what is permitted in buildings. Measured temperatures averaged $23.5 \pm 0.8^{\circ} \mathrm{C}$ and were generally within the ranges recommended for avoiding thermal discomfort. Relative humidity averaged $16 \% \pm 5 \%$, lower than what is recommended in buildings.

Key words: Commercial aircraft; Cabin air quality; In-flight measurement; Contaminants; Thermal environment.

\section{Practical Implications}

The present work provides an empirical benchmark for contaminants at the concentrations typically measured on commercial aircraft on which no tobacco smoking occurs. The information can be used to study the risk of adverse health effects and discomfort for passengers during commercial flights. The data can serve as a reference in policy documents that set the permissible levels of airborne pollutants in aircraft cabins. Aircraft manufacturers may find the present data useful in developing new tools and solutions for monitoring and mitigating elevated levels of pollutants in aircraft cabins.

\section{Abbreviations}

ACH: Air Change rate per Hour

ACGIH: American Conference of Governmental Industrial Hygienists

AHSD: Air Health Science Division office

ANSI: American National Standards Institute

AP: Aviation Regulations

ASD-STAN: Aerospace and Defence Industries Association of Europe-Standardization ASHRAE: American Society of Heating Refrigerating and Air-Conditioning Engineers 
ASTM: American Society of Testing Materials

CAA: Civil Aviation Authority

CCAC: Civil Aviation Administration of China

CEN: Comité Européen de Normalisation

CFU: Colony Forming Unit

CO: Carbon monoxide

$\mathrm{CO}_{2}$ : Carbon Dioxide

CSS: Consolidated Safety Services

DEHP: Diphenyl-2-ethylhexyl phosphate

EASA: European Aviation Safety Agency

ECS: Environmental Control System

EN: European Norm

EPA: Environmental Protection Agency

EU: European Union

FAA: Federal Aviation Administration

FH: Flight hours

FID: Flame Ionisation Detector

IAC: Russia's Interstate Aviation Committee

IAGVs: Indoor Air Guideline Values

JAA: Joint Airworthiness Authorities

LOD: Level of Detection

6-MHO: 6-methyl-5-hepten-2-one

NIOSH: National Institute for Occupational Safety and Health

NOAEL: No observed adverse effect level

NR: Not reported 
$\mathrm{O}_{3}$ : Ozone

ODT: Odour detection threshold

OEHHA: Office of Environmental Health Hazard Assessment

PELs: Permissible Exposure Levels

PID: Photo-Ionisation Detector

PM: Particulate Matter

PMV: Predicted Mean Vote

PPD: Predicted Percentage Dissatisfied

RELs: Recommended Exposure Levels

RH: Relative humidity

RSP: Respirable Suspended Particulates

SD: Standard Deviation

SI: Supplementary Information

SOA: Secondary organic aerosols

ST: Short Term Exposure Levels

SVOCs: Semi-volatile organic compounds

TBP: Triisobytyl phosphate

TCAC: Technical cabin air contamination

TCE: Trichloroethylene

TCEP: Tris (chloroethyl) phosphate

TCPP: Tris (chloro-isopropyl) phosphate

TCPs: Tricresyl phosphates

TDCPP: Tris (1,3-dichloro-isopropyl) phosphate

TEHP: Tris (ethyl-hexyl) phosphate

TiBP: Tributyl phosphate 
T-m-CP: Tri-m-cresyl phosphate

T-mmp-CP: Tri-mmp-cresyl phosphate

T-mpp-CP: Tri-mpp-cresyl phosphate

TMPP: Trimethyllolpropane phosphate

TnBP: Tri-n-butyl phosphate

TOCP: Triorthocresyl phosphate

T-p-CP: Tri-p-cresyl phosphate

TPP: Triphenyl phosphate

TBEP: Tris (butoxy-ethyl) phosphate

TXP: Trixylyl phosphate

TVOC: Total concentration of VOCs

TWA: Time Weighted Average

US: United States

VOCs: Volatile organic compounds

WHO: World Health Organization

\section{Introduction}

Commercial airlines carried more than 4.5 billion passengers in $2018^{1}$ and before the COVID19 pandemic occurred this number was expected to grow ${ }^{2}$. Around 96 billion gallons of fuel were consumed by commercial airlines worldwide in $2019^{3}$. Two to five percent of fuel is used to maintain pressurization and ventilation of the air in aircraft cabins ${ }^{4}$. Ventilation reduces the risk of adverse health effects and improves the comfort and well-being of passengers on commercial aircraft as well as the working conditions for crew members. Consequently, maintaining adequate air quality through proper ventilation and filtration of aircraft cabins is important not only from the passenger and crew members point of view but also for the airline 
because economically significant fuel savings can be achieved if the systems for maintaining cabin environmental quality are operated and controlled according to the actual pollution loads while not exceeding the permissible levels of the parameters defining the quality of air in the aircraft cabin. The ventilation of aircraft cabins is particularly energy demanding because the air is taken from the jet engines (so-called bleed air) or compressed by electrically driven compressors and must be conditioned before it can be used for ventilation. Aircraft cabin ventilation is composed typically of $60-80 \%$ outdoor air (bleed air) and $20-40 \%$ recirculated air (extracted from the cabin) $)^{5,6}$. The B787 does not use bleed air but an electric air compressor to provide outdoor air to the aircraft cabin; cabin air in the B787 contains approximately $50 \%$ fresh air and 50\% recirculated air. The National Research Council (US) Committee suggested some models of aircraft should use different amounts of recirculation or even no recirculation ${ }^{7}$ but the European Aviation Safety Agency (EASA) states that each passenger and crew compartment must be ventilated and each crew compartment must have enough outdoor air (not less than $0.28 \mathrm{~m}^{3} / \mathrm{min}$ ) to enable crewmembers to perform their duties without undue discomfort or fatigue ${ }^{8}$. The Environmental Control System (ECS) that provides conditioned air to the cabin crew and passengers is the most energy demanding sub-system of an aircraft, being responsible for up to $5 \%$ of the total fuel consumption of the engines ${ }^{9}$. The traditional ECS requires a minimum of 0.4 pounds per minute per person outside air to maintain pressurization and avionics cooling ${ }^{10}$, and the air supplied may exceed the regulatory requirement of 0.55 pounds per minute per person of outside air in order to account for flow measurement error in the bleed air supply system to the $\mathrm{ECS}^{8}$. The new optimized ECS has potential for reducing fuel consumption by reducing the ventilation rate required to achieve permissible levels of air quality. It is estimated that it could potentially save nearly $0.8 \%$ to $2 \%$ of the fuel in comparison with traditional ECS if the outdoor air supply rate could be reduced ${ }^{9,11}$. This amounts to fuel savings of between 235,000 litres $(62,000$ gallons $)$ and 587,500 litres $(155,000$ 
gallons)/year/airplane.

Ventilation is used to control the levels of pollutants generated inside the cabin as well as to remove some heat ${ }^{12}$. Ventilation removes or dilutes the pollutants generated by the occupants, their activities, the materials in the cabin and any other activities that are taking place in the cabin such as the preparation and serving of meals. Ventilation can also be the carrier of engine generated emissions as well as of contaminants present outdoors (e.g., ozone). Because commercial aircraft traffic has increased, cabin air quality and its relation to cabin ventilation has become a topic of considerable interest in recent years ${ }^{13}$. Many studies examined the effects of cabin air quality on passengers ${ }^{14-18}$ and flight attendants ${ }^{19-21}$. The types and levels of air pollutants typically measured on commercial flights must be well defined and information on how they affect comfort and well-being and the risk for adverse health effects on passengers, flight attendants and pilots must be documented for proper risk assessment and for the accurate operation of systems for controlling cabin air quality.

The present paper focuses on cabin air pollutants and extends the available information on the types of pollutants and the concentrations measured on commercial flights, which has been summarized in reviews published in the past ${ }^{15,22-24}$. We briefly summarize a few of them in the following.

Nagda et al. ${ }^{22}$ published a detailed review in 2000 of studies reporting measurements of cabin air quality that had been carried out since the mid-1980s. They reported measurements in studies of up to about 100 flights. These included information on bioaerosols, carbon monoxide $(\mathrm{CO})$, carbon dioxide $\left(\mathrm{CO}_{2}\right)$ and particulate matter $(\mathrm{PM})$. Only a few of the studies measured formaldehyde, ozone $\left(\mathrm{O}_{3}\right)$, or volatile organic compounds (VOCs); semi-volatile organic 
compounds (SVOCs) were measured but were extremely low in concentration (below detection limits of $1 \mu \mathrm{g} / \mathrm{m}^{3}$ ) and thus not reported as no conclusions could be drawn; naphthalene was the only SVOC barely above the minimum detection limits.

Space et al. ${ }^{23}$ reviewed in 2000 the same studies as Nagda et al. ${ }^{22}$ and agreed that in general the levels of pollutants measured in aircraft were low and comparable to the levels found in buildings. In particular, microbial levels in airplane cabins were found to be lower than those in a typical dwelling or office building. $\mathrm{CO}$ and respirable particulate levels were within comfort and health guidelines ${ }^{25}$, maximum $\mathrm{O}_{3}$ concentrations were lower than $\mathrm{FAA}^{25}$ regulatory limits, and formaldehyde concentrations were lower than the maximum value recommended in ASHRAE 62 Standard $^{26}$. The average reported concentrations of $\mathrm{CO}_{2}$ were about $1,500 \mathrm{ppm}$ and were thus higher than 1,000 ppm which is the upper level typically recommended in buildings for odour control, but they were not higher than is found in other means of transportation such as trains, buses, or subways. Concentrations of VOCs were measured with a variety of techniques, but the data were inadequate for developing well-founded recommendations and conclusions. It was considered possible that interactions between some pollutants and other parameters defining the quality of an aircraft cabin environment could cause discomfort for crew members or passengers.

Nagda and Rector ${ }^{15}$ published a review in 2003 of six studies involving two to thirty flights; the concentrations of both VOCs and SVOCs were reported. The review concluded that contaminant levels in aircraft cabins during routine aircraft operations were about the same as those in residential and office buildings. However, two exceptions were noted. The measured levels of ethanol and acetone were higher in aircraft than in buildings and the levels of benzene, tetrachloroethylene and xylenes were lower. It was also noted in the data from two studies that 
under normal operating conditions the levels of SVOCs, including trimethylolpropane phosphate (TMPP) and triorthocresyl phosphate (TOCP) were typically below the limits of detection. The review suggested that any generalization of results from different measuring campaigns would require data from a larger sample of flights, covering different types of aircraft and operating conditions. Furthermore, it was suggested that measured VOCs and SVOCs, although also seen in other environments, might not include the full spectrum of pollutants and their reaction products that are present in aircraft ${ }^{27}$. The authors therefore called for a comprehensive assessment of the chemical species found in aircraft cabin air.

Lindgren $^{24}$ studied in 2003 the aircraft cabin environment and identified the personal and environmental risk factors associated with symptoms and perceptions of cabin air quality. He also investigated whether a ban on smoking and increased relative humidity of air on intercontinental flights could have a beneficial health effect. The review concluded that the relative humidity, reported to be $3 \%$ to $8 \%$ during intercontinental flights, was very low. Mould and bacteria ranged between 10 and 300 Colony Forming Units $(\mathrm{CFU}) / \mathrm{m}^{3}$. Tobacco smoking, which was still permitted at the time of this study, increased the number of respirable particles present in cabin air from 3 to $49 \mu \mathrm{g} / \mathrm{m}^{3}$ and increased the amount of cotinine in urine. The exposure to tobacco smoke was highest in the aft part of the cabin, where the smoking section was located. Lindgren ${ }^{22}$ concluded that tobacco smoke and the low relative humidity of cabin air in aircraft are important environmental factors and that atopy and work stress could be significant risk factors for symptoms and adverse environmental perceptions.

The present review was a part of the ComAir ${ }^{28}$ and CognitAir projects that investigated how cabin ventilation and exposure to pollutants on commercial aircraft affect the cognitive performance, comfort, and well-being of passengers; some results obtained in these projects are 
reported elsewhere ${ }^{28}$ and all will be reported later when the analyses are completed. It was additionally initiated by the increasing interest in developing methods that would simultaneously control cabin air quality to improve comfort and reduce health risks while also reducing the increased fuel consumption caused by over-ventilating the aircraft. The overall aim was to identify all VOC studies published to date that reported measurements of air quality on aircraft and to summarize the results to create a proper reference. Among the many initial questions, the present review was intended to provide answers to the following queries: (i) How many studies performed measurements on aircraft cabin environment and how many flights on different aircraft were included in these studies? (ii) Which types of environmental parameters and contaminants were measured? (iii) What were the most measured contaminants? and (iv) What levels of each contaminant were measured? A central question was whether the measured levels of contaminants complied with the current standards and recommendations regulating aircraft cabin air quality. For this purpose, we also reviewed standards, guidelines, and regulations governing air quality in aircraft cabins and other relevant regulations and guidelines and compared them with the reported levels.

\section{Review methodology}

We searched Google Scholar, Web of Science and Research Gate for articles and reports on measurements of air quality in commercial aircraft published before November 2019. The main key words included: aircraft cabin air quality, air pollutants, gaseous contaminants, VOCs, SVOCs, particles, microorganisms. We selected primarily archival articles that provided adequate information on measurements of pollutants and their concentrations, and the measuring methods used. Our focus was mainly measurements of VOCs, but we present also all other measurements that were reported together with the VOCs in the studies that we identified during our search. 
More than 40,000 publications were found in the initial search. They were screened by reading through their titles and abstracts. Among them, forty-seven original documents were selected for the purpose of this review. We included papers reporting measurements on aircraft under normal commercial flight conditions. We did not include studies reporting measurements in the simulated mock-up of an aircraft ${ }^{29,30}$, focusing on engine emissions ${ }^{31}$, reporting unusual exposures during which crew members complained about cabin air quality ${ }^{32}$ or aimed at developing air monitoring and its applications ${ }^{33}$. The selected documents reported measurements published as early as in 1967. The following measurements were reported in the selected studies in addition to VOCs: temperature, relative humidity $(\mathrm{RH})$, ventilation, concentrations of $\mathrm{CO}_{2}, \mathrm{CO}, \mathrm{NO}_{\mathrm{x}}, \mathrm{O}_{3}$ and SVOCs, particulate matter (PM) and microorganisms. We report the measurements on non-smoking aircraft and all data including aircraft where smoking occurred are presented in SI.

The data pertinent to the objectives of the present review were extracted from the selected documents and presented both in tabular form and graphically. To create a proper reference, we extracted the following information: names of the authors, publication year, flight duration (haul-type), study location, number of flights during which the measurements were made and aircraft type. We also extracted all available information on VOC measurements and performed quality assurance/quality control (QA/QC) analysis similar to the one performed by Nagda and Rector $^{15}$; these data are presented in SI in Table S1, and in Table 9.

The average and median measured levels of the identified contaminants were calculated and presented together with the minimum and maximum levels in each study. The averages were weighted by the number of flights during which the measurements were made. Similar data 
treatment was used for other parameters that included temperature, $\mathrm{RH}$, and ventilation. The measured values reported in the forty-seven papers included in the present review were compared with the permissible levels included in the standards and guidelines. For this purpose, we reviewed standards or recommendations that are pertinent to air quality in aircraft.

We additionally compared average levels of VOCs with their published odour detection thresholds (ODT) to determine probability of detection of the pollutants that were reported. To obtain ODT we used modelled thresholds by Abraham et al. ${ }^{34}$; these modelled thresholds correlate well with the experimental ODTs obtained by Nagata and Takeuchi ${ }^{35}$.

\section{Results and discussion}

\subsection{Overview of standards and guidelines related to air quality in aircraft cabins}

Seven standards, guidelines, and regulations were collected and reviewed. They are listed in Table 1. Two of them are from the USA ${ }^{36,37}$, three from Europe ${ }^{10,38,39}$, one from Russia ${ }^{40}$, and one from China ${ }^{41}$.

Table 1 presents the specific upper limits for the air contaminants listed in these documents. These contaminants are: $\mathrm{CO}, \mathrm{CO}_{2}, \mathrm{O}_{3}$, VOCs, SVOCs, PM, bacteria, and fungi. Ventilation requirements that affect cabin air quality are also listed.

Only two documents contain upper limits for specific VOCs. These are BS-EN4618 ${ }^{39}$ and AP25 $5^{40}$; they are listed in Table 2. We present the prescribed levels in BS-EN4618 $8^{39}$ but note that the standard has been withdrawn as a result of a decision of the European committee CEN/BT $31 / 2013$. We kept this document for future reference as it is one of only two attempts to regulate the levels of VOCs on aircraft. 
BS-EN461 $8^{39}$ stipulates that the bacteria, virus and fungus limits should be those applied to the levels of micro-organisms in non-industrial indoor environments ${ }^{42}$ and in the workplace as prescribed by one European guideline ${ }^{43}$; the limits for mixed populations of fungi and bacteria, not being a main focus of the present review, are presented in Supplementary Information (SI) in Table $\mathrm{S} 12^{42}$.

It is worth mentioning that ASHRAE Standard $161^{36}$ listed in Table 1 also prescribes the quality of the thermal environment in the cabin. The temperatures should be in the range between $18.3^{\circ} \mathrm{C}-23.9^{\circ} \mathrm{C}$ both during in-flight and on-ground operations, and should not exceed $26.7^{\circ} \mathrm{C}$ during in-flight, and $26.7^{\circ} \mathrm{C}$ (with entertainment systems not operating) or $29.4^{\circ} \mathrm{C}$ (with entertainment systems in operation) on the ground. ASHRAE handbook ${ }^{44}$ suggests that typical design temperatures for commercial aircraft should be between $24^{\circ} \mathrm{C}$ and $27^{\circ} \mathrm{C}$ for hot-day ground design conditions, $21^{\circ} \mathrm{C}$ for cold-day ground-operating conditions, and $24^{\circ} \mathrm{C}$ during cruise for both, and that the air distribution system should by design provide approximately 4.7 $\mathrm{L} / \mathrm{s} / \mathrm{p}$ of outdoor air. No other recommendations are provided. Aircraft design requirements do not follow building recommendations for RH levels for occupant comfort because the upper humidity limits are imposed by safety during flight to reduce any condensation that might result in corrosion of the fuselage and the risk of electrical short-circuiting ${ }^{36}$; $\mathrm{RH}$ in $\mathrm{B} 787$ is about $25 \%$ because of the use of composite materials ${ }^{45}$. 
Table 1 Requirements regarding air quality in aircraft, where TWA stands for Time-Weighted Average.

\begin{tabular}{|c|c|c|c|c|c|c|c|}
\hline Parameter & $\mathrm{FAR}^{37}$ & ASHRAE $161^{36}$ & $\mathrm{JAR}^{38}$ & $\mathrm{CS}^{10}$ & BS-EN4618 ${ }^{39}$ & $\mathrm{CCAR}^{41}$ & $\mathrm{AP}-25^{40}$ \\
\hline $\mathrm{CO}$ & $50 \mathrm{ppm}^{*}$ & $\begin{array}{l}9 \text { ppm TWA10min } \\
50 \text { ppm } 1 \text { min peak }\end{array}$ & 50 ppm & 50 ppm & $\begin{array}{c}50 \text { ppm peak } \\
25 \text { ppm TWA1h } \\
10 \text { ppm TWA8h }\end{array}$ & $50 \mathrm{ppm}$ & $50 \mathrm{ppm}$ \\
\hline $\mathrm{O}_{3}$ & $\begin{array}{c}100 \mathrm{ppb} \\
\text { TWA } 3 \mathrm{~h} \\
250 \text { ppb any time }\end{array}$ & $\begin{array}{c}100 \mathrm{ppb} \\
\text { TWA 3h } \\
250 \text { ppb any time }\end{array}$ & $\begin{array}{c}100 \mathrm{ppb} \\
\text { TWA } 3 \mathrm{~h} \\
250 \text { ppb any time }\end{array}$ & $\begin{array}{c}100 \mathrm{ppb} \\
\text { TWA } 3 \mathrm{~h} \\
250 \text { ppb any time }\end{array}$ & $\begin{array}{c}100 \mathrm{ppb} \\
\text { TWA } 3 \mathrm{~h} \\
250 \mathrm{ppb} \text { any time } \\
60 \mathrm{ppb} \text { TWA } 8 \mathrm{~h}\end{array}$ & $\begin{array}{c}100 \mathrm{ppb} \\
\text { TWA } 3 \mathrm{~h} \\
250 \mathrm{ppb} \text { any time }\end{array}$ & $\begin{array}{c}100 \mathrm{ppb} \\
\text { TWA } 3 \mathrm{~h} \\
250 \text { ppb any time }\end{array}$ \\
\hline $\mathrm{CO}_{2}$ & 5000 ppm & - & 30000 ppm & 5000 ppm & $\begin{array}{c}20000 \text { ppm 15min } \\
5000 \text { ppm peak } \\
2,000 \text { ppm }\end{array}$ & 5000 ppm & 5000 ppm \\
\hline Ventilation rate & $\begin{array}{l}0.55 \text { pounds/min per } \\
\text { person } \\
\text { (corresponding to } 3.5 \\
\text { L/s per person) }\end{array}$ & $\begin{array}{l}\text { 3.5 L/s per person } \\
\text { (min. outside) } \\
7.1 \mathrm{~L} / \mathrm{s} \text { per person } \\
\quad \text { (min. total) }\end{array}$ & $\begin{array}{l}4.7 \mathrm{~L} / \mathrm{s} \text { per person } \\
\text { (min. outside) }\end{array}$ & $\begin{array}{l}4.7 \mathrm{~L} / \mathrm{s} \text { per person } \\
\text { (min. outside) }\end{array}$ & - & $\begin{array}{l}0.55 \text { pounds/min per } \\
\text { person } \\
\text { (corresponding to } 3.5 \\
\text { L/s per person) }\end{array}$ & - \\
\hline VOCs & - & - & - & - & See Table 2 & - & See Table 2 \\
\hline $\mathrm{PM}_{2.5}$ & - & - & - & - & $\begin{array}{c}100 \mu \mathrm{g} / \mathrm{m}^{3} \text { TWA } 1 \mathrm{~h} \\
\text { (health) } \\
40 \mu \mathrm{g} / \mathrm{m}^{3} \text { continuous } \\
\text { (health) }\end{array}$ & - & - \\
\hline $\mathrm{PM}_{10}$ & - & - & - & - & $150 \mu \mathrm{g} / \mathrm{m}^{3}$ TWA $24 \mathrm{~h}$ & - & - \\
\hline Bacteria and fungi & - & - & - & - & See Table S12 & - & - \\
\hline sVOCs & - & - & - & - & - & - & $\begin{array}{l}\text { Phosphate cresol } \\
\text { mixture } 0.5 \mathrm{mg} / \mathrm{m}^{3} \\
\text { Dioctyl sebacate } 5 \\
\mathrm{mg} / \mathrm{m}^{3}\end{array}$ \\
\hline
\end{tabular}


Table 2 Limits for specific VOCs in BS-EN4618 $8^{39}$ and for AP-25 $5^{40}$, where TWA stands for Time-Weighted Average.

\begin{tabular}{|c|c|c|c|c|}
\hline Country/Organization & VOC & $\begin{array}{c}\text { Limit } \\
\left(\mathrm{mg} / \mathrm{m}^{3}\right)\end{array}$ & Time average & Comments \\
\hline \multirow[t]{24}{*}{ BS-EN4618 } & \multirow[b]{2}{*}{ Benzene } & 3.2 & TWA 8h & Safety \\
\hline & & 12.8 & $\begin{array}{l}15 \mathrm{~min} \\
\text { exposure }\end{array}$ & Health \\
\hline & \multirow{3}{*}{ Toluene } & 760 & $\begin{array}{l}15 \mathrm{~min} \\
\text { exposure }\end{array}$ & Safety \\
\hline & & 190 & TWA 8h & Health \\
\hline & & 153 & - & Comfort \\
\hline & \multirow{3}{*}{ Formaldehyde } & 2.47 & $\begin{array}{l}15 \mathrm{~min} \\
\text { exposure }\end{array}$ & Safety \\
\hline & & 0.93 & TWA 8h & Safety \\
\hline & & $<0.1$ & $\begin{array}{l}\text { 30min } \\
\text { exposure }\end{array}$ & Health \\
\hline & \multirow{2}{*}{ Acetaldehyde } & 45 & $\begin{array}{l}15 \mathrm{~min} \\
\text { exposure }\end{array}$ & Safety \\
\hline & & 1.8 & TWA 24h & Health \\
\hline & \multirow{3}{*}{ Acrolein } & 0.75 & $\begin{array}{l}15 \mathrm{~min} \\
\text { exposure }\end{array}$ & \multirow[t]{2}{*}{ Safety } \\
\hline & & 0.25 & TWA 8h & \\
\hline & & 0.05 & TWA 30min & Health \\
\hline & \multirow{5}{*}{ Acetone } & 3630 & $\begin{array}{l}15 \mathrm{~min} \\
\text { exposure }\end{array}$ & \multirow{2}{*}{ Safety } \\
\hline & & 1210 & TWA 8h & \\
\hline & & 1782 & $\begin{array}{l}15 \mathrm{~min} \\
\text { exposure }\end{array}$ & \multirow{2}{*}{ Health } \\
\hline & & 1188 & TWA 8h & \\
\hline & & 240 & - & Comfort \\
\hline & \multirow{4}{*}{ Butanone } & 897.8 & $\begin{array}{l}15 \mathrm{~min} \\
\text { exposure }\end{array}$ & \multirow{4}{*}{ Health } \\
\hline & & 1795.5 & TWA 8h & \\
\hline & & 897.8 & $\begin{array}{c}15 \mathrm{~min} \\
\text { exposure }\end{array}$ & \\
\hline & & 598.5 & TWA 8h & \\
\hline & \multirow{2}{*}{ Dichloromethane } & $<3$ & TWA 24h & Safety \\
\hline & & $<3$ & TWA $24 \mathrm{~h}$ & Health \\
\hline \multirow[t]{7}{*}{$\mathrm{AP}-25^{40}$} & Gasoline vapor & 300 & - & Part of VOCs \\
\hline & Mineral oil vapor and aerosols & 5 & - & Part of VOCs \\
\hline & $\begin{array}{c}\text { Synthetic lubricating oil vapor and } \\
\text { aerosols }\end{array}$ & 2 & - & Part of VOCs \\
\hline & Acrolein & 0.2 & - & VOC \\
\hline & Phenol & 0.3 & - & VOC \\
\hline & Formaldehyde & 0.5 & - & VOC \\
\hline & Benzene & 5 & - & VOC \\
\hline
\end{tabular}

Notes:

- Safety Limits: limits for cabin environment parameters that if exceeded would prevent the safe operation of the aircraft.

- Health Limits: limits for cabin environment parameters that if exceeded would lead to temporary or permanent pathological effects on the occupants.

- Comfort Limits: limits for cabin environment parameters that if exceeded would prevent the achievement of an acceptable cabin environment.

- Regarding the safety and health limits, occupational exposure limits and regulatory limits are taken from cognizant authorities, where appropriate.

- Concerning an acceptable cabin environment, it is defined as one in which majority of the people exposed would not be expected to express dissatisfaction with the air quality contaminants and/or environmental criteria. 
- Comfort limits where appropriate are taken from cognizant authorities that provide indoor environment standards and guidelines.

\subsection{Overview of studies reporting measurements of air quality in aircraft}

Table 3 provides a summary of the studies included in the present review. It shows that the measurements reported were performed on 2,251 flights and that the first study was published as early as 1967. About forty different aircraft types were examined including those used for regional or intercontinental flights. The length of flight determined different categories of flight duration from very short-haul, short-haul, medium-haul to long-haul flights the categories of flight duration used in the original studies were adopted as there were differences in the methods used to categorize flight duration between various studies. Accurate determination of flight duration was considered irrelevant for the purpose of the present review.

The U.S. ban on inflight smoking began with domestic flights of two hours or less in April 1988, and was extended to domestic flights of six hours or less in February 1990, followed by the extension to all domestic and international flights in $2000^{46}$. The ban in the EU was introduced in $1997^{47}$. We therefore considered all studies published after 2000 to have reported measurements on aircraft on which smoking did not occur unless the authors stated that smoking was still taking place. For the studies published before 2000 we specifically looked for information on whether the measurements were made on aircraft where smoking did not occur, see Table 3 for details.

Table 4 summarizes parameters characterizing cabin air quality measured in the studies included in the present review together with the number of flights on which the measurements were made. VOCs and SVOCs were reported in 27 and 12 studies 
respectively on 1080 and 540 flights. PM was measured in 17 studies on a total of 451 flights. The other contaminants measured were $\mathrm{CO}, \mathrm{NO}, \mathrm{NO}_{2}, \mathrm{NO}_{\mathrm{X}}, \mathrm{SO}_{2}$; they were measured respectively on 378, 5, 37, 41 and 5 flights. Bacteria, fungi, and moulds were measured on 195, 152 and 2 flights respectively. $\mathrm{O}_{3}$ was measured in 21 studies on 1092 flights. Ventilation was measured on 364 flights in nine studies. $\mathrm{CO}_{2}$ was measured in 20 studies covering 655 flights. Fourteen studies measured temperature on 371 flights. Seventeen studies measured RH on 407 flights. The details of measurements, measurement location and $\mathrm{QA} / \mathrm{QC}$ analysis are shown in Table $\mathrm{S} 1$ in $\mathrm{SI}$; the measurements were mainly made in the passenger area. 
Table 3 Summary of studies included in the present review that reported measurements of air quality in aircraft cabins.

\begin{tabular}{|c|c|c|c|c|c|c|c|c|c|c|}
\hline \multirow[b]{2}{*}{ Study } & \multirow[b]{2}{*}{ Year } & \multirow[b]{2}{*}{$\begin{array}{l}\text { Very short- } \\
\text { haul flights }\end{array}$} & \multicolumn{3}{|c|}{ Flight type $^{a}$} & \multirow[b]{2}{*}{ Study location } & \multirow[b]{2}{*}{$\begin{array}{l}\text { Number of } \\
\text { flights }\end{array}$} & \multicolumn{3}{|c|}{ Aircraft type } \\
\hline & & & $\begin{array}{l}\text { Short-haul } \\
\text { flights }\end{array}$ & Medium-haul flights & Long-haul flights & & & Airbus & Boeing & Others \\
\hline Brabets et al. ${ }^{48}$ & 1967 & - & - & - & - & North America & 285 & & - & \\
\hline Bishof $^{49}$ & 1973 & - & - & - & - & Europe & 14 & & $\sqrt{ }$ & $\sqrt{ }$ \\
\hline Perkins et al..$^{50}$ & 1979 & - & - & - & - & North America & 2 & & $\sqrt{ }$ & \\
\hline Rogers $^{51}$ & 1980 & & $\sqrt{ }(\mathrm{NC})$ & & $\sqrt{ }(\mathrm{NC})$ & North America & 157 & $\sqrt{ }$ & $\sqrt{ }$ & $\sqrt{ }$ \\
\hline Nagda et al. ${ }^{52}$ & 1992 & - & - & - & - & North America & 92 & $\sqrt{ }$ & $\sqrt{ }$ & $\sqrt{ }$ \\
\hline Dechow et al. ${ }^{53}$ & 1997 & & & $\sqrt{ }(\mathrm{NC})$ & $\sqrt{ }(\mathrm{NC})$ & Europe & 2 & $\sqrt{ }$ & & \\
\hline ASHRAE ${ }^{54}$ & $1999^{N S}$ & & & $\sqrt{ }(\mathrm{NC})$ & $\sqrt{ }(\mathrm{NC})$ & North America & 8 & & $\sqrt{ }$ & \\
\hline Lee et al. ${ }^{55}$ & 1999 & $\begin{array}{c}\sqrt{ }(1 \mathrm{~h} \\
25 \mathrm{~min})\end{array}$ & - & - & $\sqrt{ }(14 \mathrm{~h} 15 \mathrm{~min})$ & Asia & 16 & $\sqrt{ }$ & $\sqrt{ }$ & \\
\hline Haghighat et al. ${ }^{56}$ & 1999 & - & - & - & - & North America & 43 & $\sqrt{ }$ & $\sqrt{ }$ & $\sqrt{ }$ \\
\hline Fox $^{6}$ & $2000^{\mathrm{NS}}$ & & & $\mathrm{NC}$ & & North America & 2 & & & $\sqrt{ }$ \\
\hline Dumyahn et al. ${ }^{57}$ & $2000^{\mathrm{NS}}$ & & & $N C(1 h-7.2 h)$ & & North America & 49 & & $\sqrt{ }$ & \\
\hline Ree et al. ${ }^{58}$ & 2000 & - & - & - & - & Europe & 40 & & $\sqrt{ }$ & \\
\hline Wieslander et al. ${ }^{59}$ & 2000 & - & - & - & - & Europe & 2 & & $\sqrt{ }$ & \\
\hline Nagda et al. ${ }^{60}$ & 2001 & - & - & - & - & North America & 10 & & $\sqrt{ }$ & \\
\hline Lindgren and Norbäck ${ }^{47}$ & $2002^{\mathrm{S}}$ & - & - & - & - & Europe & 26 & & $\sqrt{ }$ & \\
\hline Waters et al. ${ }^{61}$ & $2002^{s}$ & & $\sqrt{ }(<2 h)$ & $\sqrt{ }(2-8 \mathrm{~h})$ & $\sqrt{ }(>8 h)$ & North America & 36 & & - & \\
\hline & 2004-RP-1262 Part & & & & & North America & & & & \\
\hline Spicer et al. ${ }^{62}$ & 1 & & & & $\sqrt{ }(3 \mathrm{~h}-3 \mathrm{~h} 49 \mathrm{~min})$ & & 4 & & $\sqrt{ }$ & $\sqrt{ }$ \\
\hline
\end{tabular}


Spengler et al. ${ }^{63}$

\section{Duc et al. ${ }^{64}$ \\ Bhangar et al. ${ }^{65}$ \\ Muir et al. ${ }^{66}$ \\ Mckernan et al. ${ }^{67}$ \\ Osman et al. ${ }^{68}$ \\ Solbu et al. ${ }^{69}$ \\ Crump et al. ${ }^{70}$ \\ Crump et al..$^{71}$ \\ Spengler et al. ${ }^{72}$ \\ Gładyszewska- \\ Fiedoruk $^{73}$}

Giaconia et al. ${ }^{74}$

$\mathrm{Ji}$ and $\mathrm{Zhao}^{76}$

Guan et al. ${ }^{77}$

Guan et al. ${ }^{78}$
2007

2008

2008

2008

2008

2011

2011-Part 1

2011-Part 2

2012

2012

$$
2013
$$

$\checkmark$ (Lasted 3h)

$\sqrt{ }(<1.5 \mathrm{~h})$

\begin{tabular}{|c|c|c|c|c|}
\hline & North America & & & \\
\hline- & & 106 & $\sqrt{ }$ & $\sqrt{ }$ \\
\hline- & North America & 4 & & - \\
\hline- & North America & 68 & $\sqrt{ }$ & $\sqrt{ }$ \\
\hline- & Europe & 1 & & \\
\hline- & North America & 12 & & $\sqrt{ }$ \\
\hline$\sqrt{ }(\mathrm{NC})$ & North America & 16 & & $\sqrt{ }$ \\
\hline- & Europe & 40 & & \\
\hline- & Europe & 100 & $\sqrt{ }$ & $\sqrt{ }$ \\
\hline- & Europe & 100 & $\sqrt{ }$ & $\sqrt{ }$ \\
\hline$\sqrt{ }(>6 h)$ & $\begin{array}{l}\text { North America } \\
\text { Europe }\end{array}$ & 83 & $\sqrt{ }$ & $\sqrt{ }$ \\
\hline & & 1 & & - \\
\hline
\end{tabular}

North America

Asia

Asia

Asia
52 


\begin{tabular}{|c|c|c|c|c|c|c|c|c|c|c|}
\hline & 2014 & & & & & Asia & & & & \\
\hline Li et al. ${ }^{79}$ & & & $\begin{array}{l}\sqrt{ }(1 \mathrm{~h} 27 \mathrm{~min}- \\
3 \mathrm{~h} 50 \mathrm{~min})\end{array}$ & & & & 9 & & $\sqrt{ }$ & \\
\hline Ree et al. ${ }^{80}$ & 2014 & - & - & - & - & Europe & 20 & & $\sqrt{ }$ & \\
\hline Wang et al. ${ }^{81}$ & 2014 & - & - & - & - & Asia & 14 & & $\sqrt{ }$ & \\
\hline Wang et al. ${ }^{82}$ & 2014 & - & - & - & - & Asia & 14 & & $\sqrt{ }$ & \\
\hline Guan et al. ${ }^{83}$ & 2015 & - & - & - & - & Asia & 6 & & - & \\
\hline Gao et al. ${ }^{84}$ & 2015 & - & - & - & - & Asia & 5 & & $\sqrt{ }$ & \\
\hline Rosenberger et al. ${ }^{85}$ & 2016 & & $\checkmark(\mathrm{NC})$ & & $\checkmark(\mathrm{NC})$ & Europe & 108 & $\checkmark$ & & \\
\hline Schuchardt et al. ${ }^{86}$ & 2017 & & $\sqrt{ }(\mathrm{NC})$ & & $\sqrt{ }(\mathrm{NC})$ & Europe & 69 & $\sqrt{ }$ & $\sqrt{ }$ & \\
\hline Cao et al..$^{87}$ & 2017 & & $\checkmark(\mathrm{NC})$ & & & Asia & 64 & $\sqrt{ }$ & $\sqrt{ }$ & \\
\hline Cao et al. ${ }^{88}$ & 2018 & & $\sqrt{ }(<2 h)$ & $\sqrt{ }(2-6 h)$ & & Asia & 179 & $\sqrt{ }$ & $\sqrt{ }$ & $\sqrt{ }$ \\
\hline Rosenberger ${ }^{14}$ & 2018 & - & - & - & - & Europe & 17 & $v$ & & \\
\hline Schuchardt et al. ${ }^{89}$ & 2019 & - & - & - & - & Europe & 177 & $\sqrt{ }$ & $v$ & \\
\hline Guan et al. ${ }^{90}$ & 2019 & - & - & - & - & Asia & 14 & $v$ & $v$ & \\
\hline Liu et al. ${ }^{91}$ & 2019 & - & - & - & - & Asia & 7 & $\checkmark$ & $\sqrt{ }$ & \\
\hline Total & 1967-2019 & 1 & 11 & 5 & 10 & & 2251 & 22 & 35 & 12 \\
\hline
\end{tabular}

Notes:

- NC: not clear

- a: length of flight according to the information provided in the reviewed papers; it was not possible to provide the length of flights in minutes/hours.

- Studies reported after 2000 are on non-smoking flights unless indicated with $S$ at the date; studies before 2000 were considered to be carried out on smoking flights unless indicated NS at the date. 
Table 4 Number of flights on which air quality parameters were measured in the studies selected for the present review.

\begin{tabular}{|c|c|c|c|c|c|c|c|c|c|c|c|c|c|c|c|c|c|}
\hline \multirow{2}{*}{ Study } & \multirow{2}{*}{ Year } & \multicolumn{16}{|c|}{ Parameters measured in aircraft cabin (Flight number) } \\
\hline & & Temperature & $\mathrm{RH}$ & Ventilation & $\mathrm{CO}_{2}$ & $\mathrm{O}_{3}$ & VOCs & svocs & Particulates & $\mathrm{CO}$ & NO & $\mathrm{NO}_{2}$ & $\mathrm{NO}_{\mathrm{x}}$ & $\mathrm{SO}_{2}$ & Bacteria & Fungi & Molds \\
\hline Brabets et al. ${ }^{48}$ & 1967 & & & & & 285 & & & & & & & & & & & \\
\hline 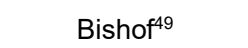 & 1973 & & & & & 14 & & & & & & & & & & & \\
\hline Perkins et al..$^{50}$ & 1979 & & & & & 2 & & & & & & & & & & & \\
\hline Rogers $^{51}$ & 1980 & & & & & 157 & & & & & & & & & & & \\
\hline Nagda et al. ${ }^{52}$ & 1992 & 92 & 92 & 35 & 92 & 92 & & & 92 & 92 & & & & & 92 & 92 & \\
\hline Dechow et al..$^{33}$ & 1997 & & & & & & 2 & & 2 & & & & & & 2 & & \\
\hline ASHRAE ${ }^{54}$ & 1999 & 8 & 8 & & 8 & 8 & 8 & & 8 & 8 & & & & & 8 & 8 & \\
\hline Lee et al. ${ }^{55}$ & 1999 & 16 & 16 & & 16 & 16 & 5 & & 8 & 8 & 5 & 5 & 5 & 5 & 3 & 3 & \\
\hline Haghighat et al. ${ }^{56}$ & 1999 & 43 & 43 & & 43 & & & & & & & & & & & & \\
\hline Fox $^{6}$ & 2000 & 2 & 2 & & 2 & & 2 & 2 & & 2 & & & & & & & \\
\hline Dumyahn et al. ${ }^{57}$ & 2000 & 49 & 49 & & 49 & 27 & 49 & & 49 & 49 & & 27 & & & 49 & 49 & \\
\hline Ree et al..$^{58}$ & 2000 & & 18 & & & 31 & & & & & & & & & & & \\
\hline Wieslander et al. 59 & 2000 & 2 & 2 & & 2 & 2 & 2 & & 2 & & & & & & 2 & & 2 \\
\hline Nagda et al. ${ }^{60}$ & 2001 & 10 & 10 & & 10 & & 10 & 10 & 10 & 10 & & & & & & & \\
\hline $\begin{array}{l}\text { Lindgren and } \\
\text { Norbäck }^{47}\end{array}$ & 2002 & 5 & 5 & 24 & 5 & 13 & 22 & & 26 & & & 5 & & & & & \\
\hline Waters et al. ${ }^{61}$ & $\begin{array}{c}2002 \\
2004-\mathrm{RP}-\end{array}$ & 36 & 36 & & 36 & 36 & 36 & & 36 & 36 & & & 36 & & & & \\
\hline Spicer et al. ${ }^{62}$ & $\begin{array}{c}1262 \text { Part } \\
1\end{array}$ & 4 & 4 & 4 & 4 & 4 & 4 & 4 & 4 & 4 & & & & & & & \\
\hline Spengler et al. ${ }^{63}$ & 2004 & & & & & 106 & & & & & & & & & & & \\
\hline Duc et al. .4 & 2007 & & & & & & & & & & & & & & 4 & & \\
\hline Bhangar et al. ${ }^{65}$ & 2008 & & & & & 68 & & & & & & & & & & & \\
\hline Muir et al. ${ }^{66}$ & 2008 & & & & & & 1 & 1 & & & & & & & & & \\
\hline Mckernan et al. ${ }^{67}$ & 2008 & & & & & & & & & & & & & & 12 & & \\
\hline Osman et al. ${ }^{68}$ & 2008 & & & & & & & & & & & & & & 16 & & \\
\hline Solbu et al .69 & 2011 & & & & & & 31 & 40 & & & & & & & & & \\
\hline
\end{tabular}




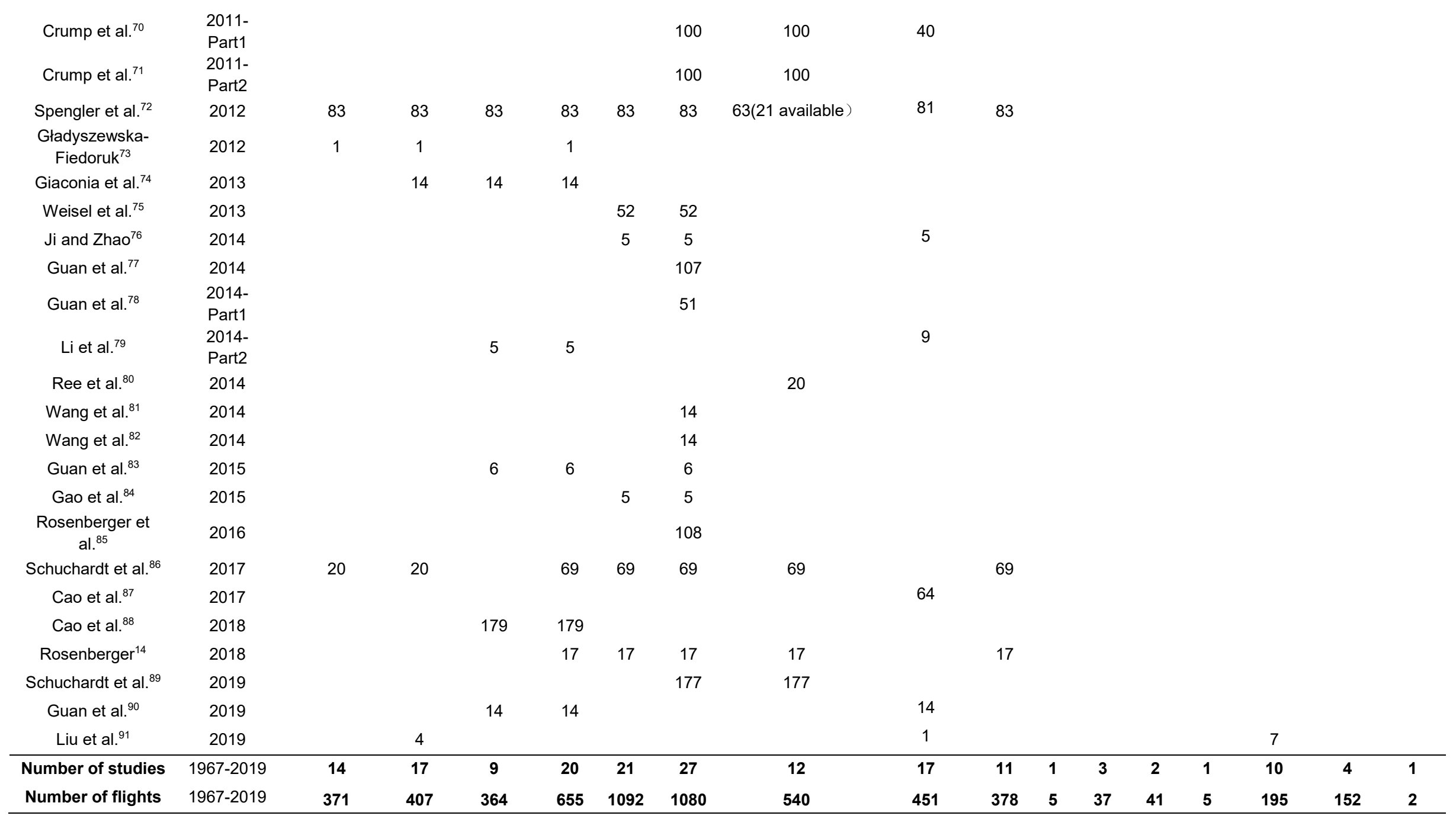




\subsection{Measured VOCs}

Different methods were used to detect and analyse VOCs in studies included in the present review. We grouped the results according to the method used.

Two methods were used to monitor the total concentration of VOCs (TVOCs). These were the Flame Ionisation Detector (FID) ${ }^{55}$ and the Photo-Ionisation Detector $(\mathrm{PID})^{70,71,83,86}$. Average TVOC concentration measured using a real-time FID monitor was about $8 \mathrm{mg} / \mathrm{m}^{3}$. Average TVOC concentration measured using a real-time PID method was $277 \mu \mathrm{g} / \mathrm{m}^{3}$; the range was from 0 to $38 \mathrm{mg} / \mathrm{m}^{3}$. FID is often reported as ppb methane and PID as ppb isobutylene equivalent; Schuchardt et $a .^{89}$ reported it as Toluene equivalent in $\mu \mathrm{g} / \mathrm{m}^{3}$. We were not able to determine the calibration details for these detectors, but they may explain the large differences in TVOC observed between the two methods.

Three sampling methods were used to measure VOCs: active sampling, passive sampling, and canister sampling. Active sampling was used in the majority of the studies included in the present review, resulting in 140 measured VOCs ${ }^{53,54,61,70-}$ $72,75,76,78,81,82,84-86$. There is no detailed concentration data on the type of contaminants for other active sampling studies of VOCs ${ }^{14,69,77,83,89}$. Passive sampling was used in a few studies resulting in 48 measured $\operatorname{VOCs}^{47,59,62,92}$, while canister sampling was used in five studies resulting in 96 measured VOCs ${ }^{60,62,72}$. As active sampling detected more compounds and was used in the greatest number of studies the results obtained in this way are presented below. All other measurements are tabulated in SI where a distinction is made between the compounds measured on all flights and on non-smoking flights 
only.

The concentrations of VOCs measured using active sampling were in the range from 0 to $3 \mathrm{mg} / \mathrm{m}^{3}$ with the average concentration ranging between 0.1 and $100 \mu \mathrm{g} / \mathrm{m}^{3}$. For non-smoking flights, Figure 1 shows the VOCs measured in 12 studies. Fifteen classes of VOCs were measured, with alcohols accounting for most of the compounds measured $(57.8 \%)$ followed by aldehydes $(6.4 \%)$, alkanes $(4.8 \%)$, terpenes $(4.5 \%)$, aromatics (3.5\%) and ketones (3.4\%); all other groups of VOCs each accounted for less than $3 \%$ of the compounds measured (Figure 1). Comparing concentrations of measured VOCs with the permissible levels set out by AP- $25^{40}$ and the now withdrawn BS-EN4618 ${ }^{39}$, it can be seen that even the maximum concentrations of the listed compounds measured in the aircraft cabins were lower than the prescribed limits (Table $5)$.

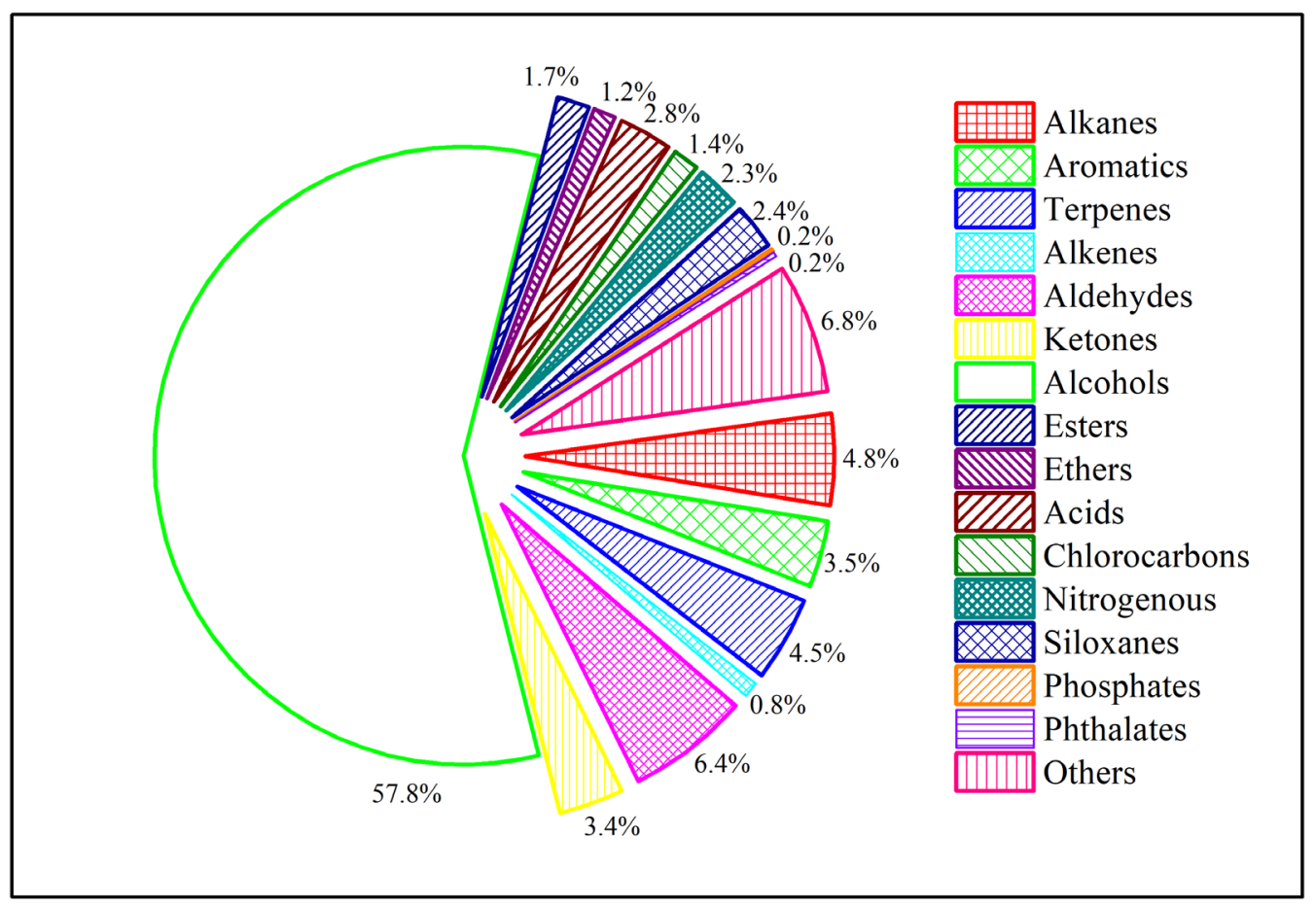

Figure 1 VOCs measured on non-smoking aircraft in 12 studies classified by chemical functional group $54,70-72,75,76,78,81,82,84-86$. 
Table 5 Concentrations of measured VOCs in non-smoking commercial flights compared with the permissible levels set out by BS-EN4618 ${ }^{39}$ (withdrawn) and AP-25

${ }^{40}$, where TWA stands for Time Weighted Average.

\begin{tabular}{|c|c|c|c|c|c|c|c|c|}
\hline \multirow{2}{*}{ VOC } & \multirow{2}{*}{$\begin{array}{c}\text { Chemical } \\
\text { Abstract } \\
\text { System (CAS) } \\
\text { no. }\end{array}$} & \multicolumn{4}{|c|}{ Concentration $\left(\mu \mathrm{g} / \mathrm{m}^{3}\right)$} & \multirow{2}{*}{ Limit $\left(\mathrm{mg} / \mathrm{m}^{3}\right)$} & \multirow{2}{*}{ Time average } & \multirow{2}{*}{ Comments } \\
\hline & & Avg. & SD & Min. & Max. & & & \\
\hline Benzene & $71-43-2$ & 5.9 & 5.5 & 0.0 & 78 & $\begin{array}{c}3.2^{39} \\
12.8^{39}\end{array}$ & $\begin{array}{c}\text { TWA 8h } \\
\text { 15min exposure }\end{array}$ & $\begin{array}{l}\text { Safety } \\
\text { Health }\end{array}$ \\
\hline Toluene & $108-88-3$ & 15 & 12 & 0.0 & 209 & $\begin{array}{l}760^{39} \\
190^{39} \\
153^{39}\end{array}$ & $\begin{array}{c}\text { 15min exposure } \\
\text { TWA 8h } \\
-\end{array}$ & $\begin{array}{l}\text { Safety } \\
\text { Health } \\
\text { Comfort }\end{array}$ \\
\hline Formaldehyde & $50-00-0$ & 5.4 & 1.5 & 0.0 & 44 & $\begin{array}{c}2.47^{39} \\
0.93^{39} \\
<0.1^{39} \\
0.5^{40}\end{array}$ & $\begin{array}{c}\text { 15min exposure } \\
\text { TWA 8h } \\
\text { 30min exposure }\end{array}$ & $\begin{array}{l}\text { Safety } \\
\text { Safety } \\
\text { Health } \\
\text { VOC }\end{array}$ \\
\hline Acetaldehyde & $75-07-0$ & 6.4 & 1.2 & 0.3 & 90 & $\begin{array}{l}45^{39} \\
1.8^{39}\end{array}$ & $\begin{array}{c}\text { 15min exposure } \\
\text { TWA } 24 \mathrm{~h}\end{array}$ & $\begin{array}{l}\text { Safety } \\
\text { Health }\end{array}$ \\
\hline Acrolein & $107-02-8$ & $<0.8$ & 1.0 & 0.0 & 53 & $\begin{array}{c}0.75^{39} \\
0.25^{39} \\
0.05^{39} \\
0.2^{40}\end{array}$ & $\begin{array}{c}\text { 15min exposure } \\
\text { TWA 8h } \\
\text { TWA 30min } \\
-\end{array}$ & $\begin{array}{l}\text { Safety } \\
\text { Health } \\
\text { VOC }\end{array}$ \\
\hline Acetone & $4468-52-4$ & 14 & 5.6 & $<$ LOD & 384 & $\begin{array}{c}3630^{39} \\
1210^{39} \\
1782^{39} \\
1188^{39} \\
240^{39}\end{array}$ & $\begin{array}{c}\text { 15min exposure } \\
\text { TWA 8h } \\
\text { 15min exposure } \\
\text { TWA 8h } \\
-\end{array}$ & $\begin{array}{l}\text { Health } \\
\text { Comfort }\end{array}$ \\
\hline Butanone & $78-93-3$ & 2.4 & 0.8 & 0.0 & 32 & $\begin{array}{c}897.8^{39} \\
1795.5^{39} \\
897.8^{39} \\
598.5^{39}\end{array}$ & $\begin{array}{c}\text { 15min exposure } \\
\text { TWA 8h } \\
\text { 15min exposure } \\
\text { TWA } 8 \mathrm{~h}\end{array}$ & $\begin{array}{l}\text { Safety } \\
\text { Health }\end{array}$ \\
\hline Phenol & $108-95-2$ & 1.2 & 0.1 & 0.1 & 5.0 & $0.3^{40}$ & - & VOC \\
\hline
\end{tabular}

Note: in some cases, the admissible levels for 8-hour exposure are higher than admissible levels for 30 min exposure; the reason is that they refer to different outcomes, as indicated in the table above. 
Table 6 shows a list of compounds that were measured in two or more studies, with the highest concentration, with the lowest ODTs. The compounds most frequently appearing on these lists were toluene, benzene, ethylbenzene, formaldehyde, acetaldehyde, limonene, nonanal, hexanal, decanal, octanal, butanal, acetic acid, acetone, ethanol, acrolein, isoprene, and menthol; aldehydes and acids were with the lowest ODTs (the SI provides more detail). Table 7 shows compounds that were frequently measured (measured in $\geq 2$ studies) and compared with some examples of Indoor Air Guideline Values (IAGVs) for VOCs proposed by WHO, US and in various other countries.

Toluene, benzene and ethylbenzene are fuel-related and engine-related compounds ${ }^{39}$, and toluene concentration was previously regulated ${ }^{39}$. The maximum measured concentrations of toluene (Table 7 ) were lower than the previously recommended maximum level of toluene (Table 2). Toluene was among the few pollutants that were most frequently found to be present on aircraft at high concentrations (Table 6 and Table S10 in SI); this reflects the sampling methods applied collecting mainly hydrocarbons and not oxygenates and other miscellaneous compounds. According to the Indoor Air Guideline Values (IAGVs) (Table 7), the average benzene concentration of $5.9 \pm 5.5 \mu \mathrm{g} / \mathrm{m}^{3}$ exceeded the 8-hour Recommended Exposure Levels (RELs) and the Chronic RELs ${ }^{93}$. Benzene is a genotoxic carcinogen in humans and no safe level of exposure can be recommended. The geometric mean of the range of the estimates of the excess lifetime risk of leukaemia at an air concentration of $1 \mu \mathrm{g} / \mathrm{m}^{3}$ is $6 \times 10^{-6}$. The concentrations of airborne benzene associated with an excess lifetime risk of $1 / 10,000$, $1 / 100,000$ and $1 / 1,000,000$ are $17,1.7$ and $0.17 \mu \mathrm{g} / \mathrm{m}^{3}$, respectively. The average level 
of benzene measured on aircraft was around $5.9 \pm 5.5 \mu \mathrm{g} / \mathrm{m}^{3}$ which corresponds to excess lifetime risk of leukemia of $1 / 30,000^{94}$. Figure S1 in SI presents the relationship between measured toluene and benzene levels in 5 studies ${ }^{66,76,78,81,86}$ that can be used to estimate benzene levels based on the toluene levels. It shows that the concentration of toluene is twice that of benzene.

Formaldehyde and acetaldehyde are likely to have been products of the $\mathrm{O}_{3}$ chemistry that occurs in aircraft ${ }^{95-97}$, and associated with lubricant and hydraulic oils and fuel ${ }^{39}$. They were being considered for regulation by BS-EN $4618^{39}$ before it was withdrawn (Table 2 and Table 5).

Many sources can emit limonene, such as fragrances in aircraft cabins, fragrances in wet napkins, cleaning agents and deodorizers ${ }^{97,98}$, as well as from soft drinks ${ }^{99}$ and (earl grey) tea ${ }^{100}$ and citrus fruits ${ }^{99}$. It is one of pollutants that was measured frequently and at high concentration (Table 6). It is also worth mentioning that limonene was frequently detected on cabin air filters at $4 \mathrm{mg} / \mathrm{g}$ carbon $(6.0 \%$ of the total mass of all compounds) that had been used for 660 flight hours, and at $6 \mathrm{mg} / \mathrm{g}$ carbon $(3.7 \%$ of the total mass of all compounds) on filters that had been used for 3,937 flight hours ${ }^{101}$. Limonene can undergo chemical transformations. Reactions with $\mathrm{O}_{3}$ can produce secondary organic aerosols (SOAs) $)^{102,103}$ and aldehydes $^{97,98}$, among others formaldehyde and acetaldehyde, and oxy and poly-oxygenated gaseous VOCs/SVOCs.

Nonanal, capronaldehyde/hexaldehyde/hexanal, decanal and octanal were detected frequently in aircraft cabins at high concentrations (Table 6). These pollutants are associated with the presence of humans but are the results of heterogeneous reactions 
between $\mathrm{O}_{3}$ and human skin oils ${ }^{75,84,104}$. Skin oils are present on human skin but can also be present on clothing and on all surfaces that have been touched by human skin, such as seats, armrests, and headrests.

The products of the chemical reaction between squalene and $\mathrm{O}_{3}$ is one of the sources of acetic acid in aircraft cabins ${ }^{84}$, which is one of the pollutants that were measured frequently at high concentration (Table 6). Ethanol is associated with emissions from humans due to metabolic processes (or consumption of alcohol) ${ }^{105}$, it is one of pollutants that was measured frequently and at the highest concentration (Table 6). Acetone is also a pollutant emitted by humans ${ }^{105}$ that was one of the compounds measured most frequently and with the highest concentrations on aircraft (Table 6); acetone was being considered for regulation by BS-EN $4618^{39}$ before it was withdrawn (Table 2). 
Table 6 The list of compounds that were measured with the highest average concentration and those that were measured in more than two studies and had lowest ODT; the most common pollutants are in bold on each list.

\begin{tabular}{|c|c|c|}
\hline $\begin{array}{l}\text { Compounds with the highest average } \\
\text { concentration }\end{array}$ & Measured in $\geq 2$ studies & $\begin{array}{l}\text { Compounds with the } \\
\text { lowest ODT }{ }^{34}\end{array}$ \\
\hline Ethanol & Toluene & Isovaleraldehyde \\
\hline 1-Propanol & Limonene & Octanal \\
\hline Isoalkanes C14-C20 & m\&p-Xylene & $\begin{array}{c}\text { Capronaldehyde/ } \\
\text { Hexaldehyde/ } \\
\text { Hexanal }\end{array}$ \\
\hline 1,2-Propanediol & Benzene & $\begin{array}{l}\text { n-Butyraldehyde/ } \\
\text { Butanal }\end{array}$ \\
\hline Limonene & Benzaldehyde & Valeraldehyde \\
\hline Acetonitrile & Undecane & Decanal \\
\hline Hexane & o-Xylene & Acetaldehyde \\
\hline Cyclopentasiloxane & Ethylbenzene & Nonanal \\
\hline Toluene & Styrene & Propionaldehyde \\
\hline Decanal & Nonanal & Hexanoic acid \\
\hline Acetone & Acrolein & Octanoic acid \\
\hline Acetic acid & Formaldehyde & Acrolein \\
\hline Isopropyl alcohol & Capronaldehyde/Hexaldehyde/Hexana & Acetic acid \\
\hline Menthol & $\begin{array}{l}\text { Tetrachloroethene/Tetrachloroethylene/P } \\
\text { erchlorethylene }\end{array}$ & Butyl acetate \\
\hline Nonanal & Decanal & Phenol \\
\hline 1-Hexanol,2-ethyl- & Acetone & Methacrolein \\
\hline $\begin{array}{l}\text { Tetrachloroethene/Tetrachloroethylene/P } \\
\text { erchlorethylene }\end{array}$ & Dodecane & Ethylbenzene \\
\hline 6-methyl-5-hepten-2-one/6-MHO & 6-methyl-5-hepten-2-one/6-MHO & Crotonaldehyde \\
\hline $\begin{array}{c}\mathrm{N}, \mathrm{N}- \\
\text { dimethylformamide/Dimethylformamide }\end{array}$ & Trichloroethene & Isoprene \\
\hline Isoprene & Acetaldehyde & Menthol \\
\hline Ethyl acetate & Isoprene & \\
\hline Acetaldehyde & Ethyl acetate & \\
\hline Benzene & p-dichlorobenzene/1,4-dichlorobenzene & \\
\hline Dioctyl ether & Hexane & \\
\hline Formaldehyde & Octanal & \\
\hline Capronaldehyde/Hexaldehyde/Hexana & Nonane & \\
\hline Benzoic acid & Heptane & \\
\hline Perfluoro derivates & Decane & \\
\hline \multirow[t]{10}{*}{ 1,3-Butanediol } & Acetic acid & \\
\hline & n-Butyraldehyde/Butanal & \\
\hline & Butanone/2-butanone & \\
\hline & 2,2,4-Trimethylpentane dioldiisobutyrate & \\
\hline & Isopropyl alcohol & \\
\hline & Dichlormethane/methylene chloride & \\
\hline & Methylcyclohexane & \\
\hline & $\begin{array}{c}\text { Heptanal } \\
\mathrm{N}, \mathrm{N}- \\
\text { dimethylformamide/Dimethylformamide } \\
\text { 2-ethyl-1-hexanol/2-Ethylhexanol }\end{array}$ & \\
\hline & Menthol & \\
\hline & Ethanol & \\
\hline
\end{tabular}


Tridecane

Pentane

3-Carene

a-Pinene

b-Pinene

Octane 
Table 7 Examples of Indoor Air Guideline Values (IAGVs) for VOCs proposed by WHO, US and in various countries; the list of compounds that were frequently measured (measured in $\geq 2$ studies), where TWA stands for Time-Weighted Average.

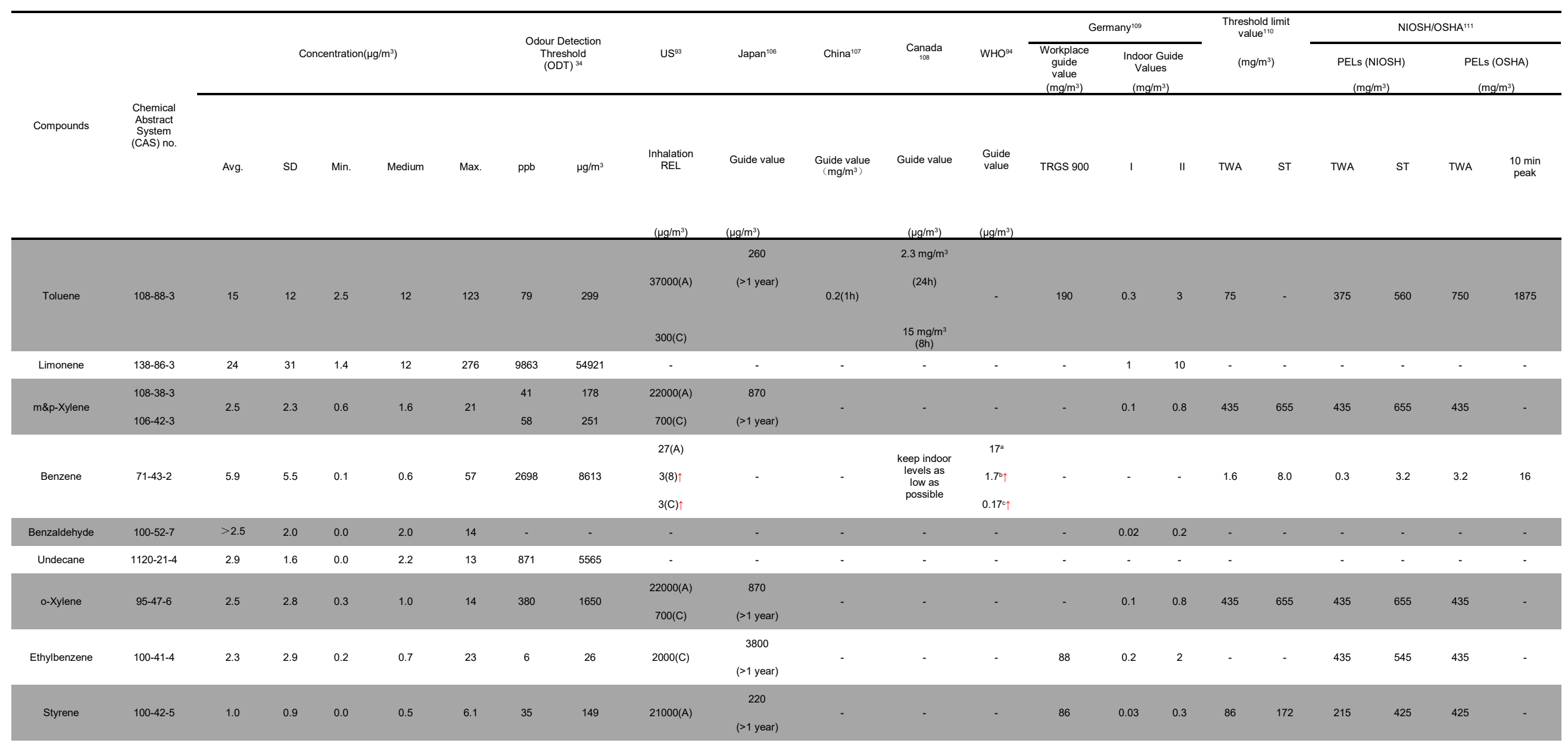




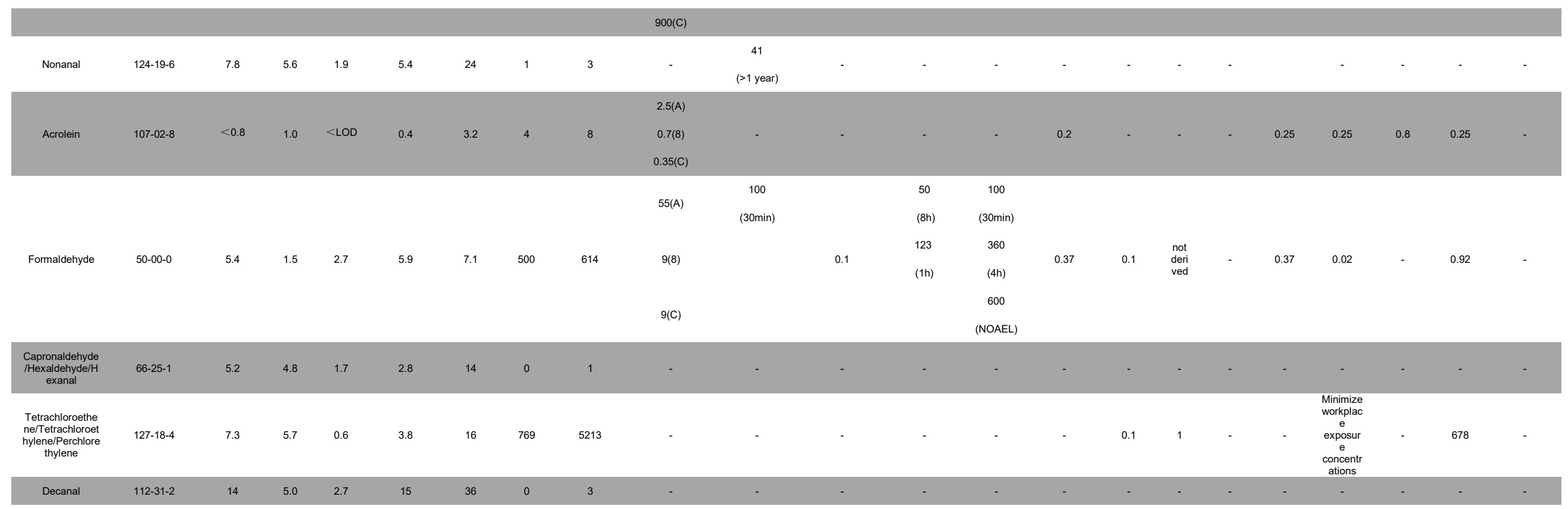

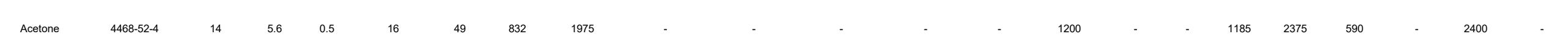

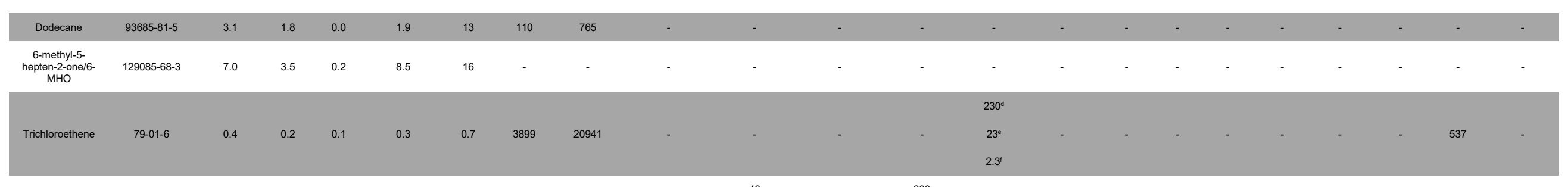

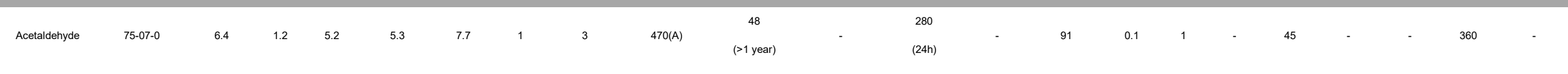




\begin{tabular}{|c|c|c|c|c|c|c|c|c|c|c|c|c|c|c|c|c|c|c|c|c|c|c|}
\hline & & & & & & & & & $\begin{array}{l}300(8) \\
140(\mathrm{C})\end{array}$ & & & $\begin{array}{l}1420 \\
\text { (1h) }\end{array}$ & & & & & & & & & & \\
\hline Isoprene & 78-79-5 & 6.8 & 4.9 & 0.8 & 9.0 & 14 & 49 & 135 & - & - & - & - & - & 8.4 & - & - & - & - & - & - & & \\
\hline Ethyl acetate & $141-78-6$ & 6.5 & 4.4 & 3.9 & 4.9 & 16 & 245 & 884 & & & & & - & 730 & 0.6 & 6 & 1400 & - & 1400 & - & 1400 & - \\
\hline $\begin{array}{c}\mathrm{p}- \\
\text { dichlorobenzene } \\
11,4- \\
\text { dichlorobenzene }\end{array}$ & $106-46-7$ & 2.4 & 2.9 & 0.1 & 1.0 & 6.9 & - & - & $800(\mathrm{C})$ & $\begin{array}{l}240 \\
(>1 \text { year) }\end{array}$ & - & - & - & 12 & - & - & 60 & - & - & - & 450 & - \\
\hline Hexane & $110-54-3$ & 20 & 31 & 0.0 & 0.5 & 68 & 1500 & 5283 & $700(\mathrm{C})$ & & & & - & 180 & - & - & 1800 & 3600 & 1800 & - & & \\
\hline Octanal & $124-13-0$ & 4.2 & 1.8 & 1.3 & 2.9 & 10 & 0.2 & 0.9 & - & - & - & - & 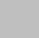 & - & 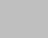 & 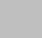 & - & - & - & - & - & - \\
\hline Nonane & $111-84-2$ & $>1.4$ & 0.7 & 0.0 & 1.8 & 2.0 & 2198 & 11522 & - & - & - & - & - & - & - & - & 1393 & - & - & - & & \\
\hline Heptane & $142-82-5$ & $>0.7$ & 0.3 & 0.0 & 0.9 & 0.9 & 670 & 2744 & - & - & - & - & - & 2100 & - & - & 1600 & 2000 & 2000 & - & 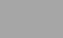 & 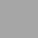 \\
\hline Decane & $124-18-5$ & 1.1 & 0.6 & 0.0 & 1.0 & 1.7 & 619 & 3603 & - & - & - & - & - & - & - & - & - & - & - & - & - & - \\
\hline Acetic acid & 64-19-7 & 11 & 2.7 & 1.1 & 12 & 16 & 5 & 13 & - & - & - & - & - & - & - & - & 25 & 37 & 25 & 37 & 25 & - \\
\hline $\begin{array}{c}\text { n- } \\
\text { Butyraldehyde/B } \\
\text { utanal }\end{array}$ & $123-72-8$ & 1.0 & 0.2 & 0.8 & 0.9 & 1.3 & 0 & 1 & & & & & & 64 & & & - & - & - & - & - & - \\
\hline $\begin{array}{c}\text { Butanone/2- } \\
\text { butanone- }\end{array}$ & 78-93-3 & 2.4 & 0.8 & 1.2 & 2.9 & 2.9 & 440 & 1296 & - & - & - & - & - & 600 & - & - & - & - & 590 & 885 & 590 & - \\
\hline $\begin{array}{c}2,2,4- \\
\text { Trimethylpentan } \\
\mathrm{e} \\
\text { dioldiisobutyrate }\end{array}$ & NO & 1.1 & 0.3 & 0.2 & 1.0 & 1.3 & - & - & - & - & - & - & - & - & - & - & - & - & - & - & - & - \\
\hline Isopropyl alcohol & $67-63-0$ & 10 & 3.4 & 3.5 & 13 & 13 & $\begin{array}{c}50118 \\
7\end{array}$ & 1231222 & & & & & - & - & - & - & - & - & 980 & 1225 & 980 & - \\
\hline $\begin{array}{l}\text { Dichlormethane/ } \\
\text { methylyene } \\
\text { chloride }\end{array}$ & $75-09-2$ & 1.4 & 1.0 & 0.0 & 1.1 & 2.8 & $\begin{array}{c}16000 \\
0\end{array}$ & 555448 & - & - & - & - & - & 180 & - & - & & & - & - & - & - \\
\hline $\begin{array}{l}\text { Methylcyclohexa } \\
\text { ne }\end{array}$ & $108-87-2$ & 0.6 & 0.5 & 0.1 & 0.6 & 1.1 & 150 & 602 & - & - & - & - & - & 810 & - & - & 1600 & - & 1600 & - & 2000 & - \\
\hline Heptanal & $111-71-7$ & 3.2 & 1.3 & 0.7 & 2.3 & 4.6 & 30 & 140 & - & - & - & - & - & - & - & - & - & - & - & - & - & - \\
\hline $\begin{array}{l}\mathrm{N}, \mathrm{N}- \\
\text { dimethylformami } \\
\text { de/Dimethylform } \\
\text { amide }\end{array}$ & $68-12-2$ & $<6.8$ & 3.9 & 0.0 & 7.7 & 7.7 & - & - & - & - & - & - & - & 15 & - & - & $\begin{array}{c}30 \\
\text { [skin] }\end{array}$ & - & 30 [skin] & & $\begin{array}{l}30 \\
\text { [skin] }\end{array}$ & \\
\hline
\end{tabular}




\begin{tabular}{|c|c|c|c|c|c|c|c|c|c|c|c|c|c|c|c|c|c|c|c|c|c|c|}
\hline $\begin{array}{l}\text { 2-ethyl-1- } \\
\text { hexanol/2- } \\
\text { Ethylhexanol }\end{array}$ & $104-76-7$ & 4.7 & 1.0 & 2.9 & 4.0 & 5.9 & 74 & 395 & - & - & - & - & - & 0.1 & - & - & - & - & - & - & - & - \\
\hline Menthol & $\begin{array}{c}15356-70-4 \\
491-02-1\end{array}$ & 9.6 & 3.6 & 1.0 & 12 & 12 & 22 & 140 & - & - & - & - & - & - & - & - & - & - & - & - & - & - \\
\hline Ethanol & $64-17-5$ & 386 & 899 & 81 & 82 & 3009 & 331 & 624 & - & - & - & - & - & 380 & - & - & - & 1900 & 1900 & - & 1900 & - \\
\hline Tridecane & $629-50-5$ & 1.5 & 0.4 & 0.0 & 1.7 & 1.7 & - & - & - & - & - & - & - & - & - & - & - & - & - & - & - & - \\
\hline Pentane & $109-66-0$ & 1.4 & 0.4 & 0.4 & 1.4 & 4.7 & 1400 & 4128 & - & - & - & - & - & 3000 & - & - & 1770 & - & 350 & - & 2950 & - \\
\hline 3-Carene & $13466-78-9$ & 1.1 & 0.5 & 0.0 & 1.3 & 1.3 & 1671 & 9305 & - & - & - & - & - & - & - & - & - & - & - & - & - & - \\
\hline a-Pinene & $80-56-8$ & 1.1 & 0.3 & 0.0 & 1.2 & 1.2 & 18923 & 105374 & - & - & - & - & - & - & - & - & - & - & - & - & - & - \\
\hline b-Pinene & $127-91-3$ & 0.5 & 0.2 & 0.0 & 0.6 & 0.6 & 11749 & 65424 & - & - & - & - & - & - & - & - & - & - & - & - & - & - \\
\hline Octane & $111-65-9$ & $>0.5$ & 0.1 & 0.0 & 0.5 & 0.6 & 1698 & 7929 & - & - & - & - & - & 2400 & - & - & 2350 & - & 350 & - & 1410 & - \\
\hline
\end{tabular}

- concentration (average, SD, average minimum, average medium, average maximum).

- $\mathrm{A}=$ acute, 8 = 8-hour, $\mathrm{C}=$ chronic. Exposure averaging time for acute RELs is 1 hour. For 8-hour RELs, the exposure averaging time is 8 hours, which may be repeated. Chronic RELs are designed to address continuous exposures for up to a lifetime: the exposure metric used is the annual average exposure.

- a: an excess lifetime risk of $1 / 10000$.

- b: an excess lifetime risk of $1 / 100000$.

- c: an excess lifetime risk of $1 / 1000000$.

- d: an excess lifetime cancer risk of $1 / 10000$

- e: an excess lifetime cancer risk of $1 / 100000$.

- $f:$ an excess lifetime cancer risk of 1:1000000

- NOAEL: no observed adverse effect level.

- PELs: Permissible Exposure Levels.

- ST: Short Term Exposure Levels.

- $\uparrow$ : means the average was higher than the guideline value. 


\subsection{Measured SVOCs}

The presence of a range of SVOCs in aircraft cabin and cockpit air has been recorded in several studies ${ }^{69,80,85,89,112-117}$. The cabin air supply in most jet aircraft is obtained by extraction of heated and compressed bleed air from the jet engine cores, prior to mixing with filtered recycled cabin air. Furthermore, the aircraft hydraulic reservoir vent is connected to the cabin air ventilation system, making it possible for hydraulic oil aerosols to enter cabin air ${ }^{118}$; they also have other sources as shown by Schuchardt et $\mathrm{al}^{89}$. SVOCs have been suspected as the source of hazardous neurotoxic substances and potentially responsible for some of the reported health effects in aircraft cabins and flight decks ${ }^{19,80,112}$. Because of technical difficulties, measurements of SVOCs in aircraft cabins have been in focus only in recent years. Nagda and Rector ${ }^{15}$ reported that under normal operating conditions the levels of SVOCs other than tricresyl phosphates (TCPs) (which does not have anything to do with hydraulic systems) but including TMPP and TOCP, originating most likely from engine oil contamination of the cabin air and TBP (tributyl phopsphate) originating from hydraulic oil, are typically below the detection limits. This agrees with the operation of the ventilation system on aircraft. Bleed air is used to pressurize the hydraulic fluid reservoir and fresh-water tank on some aircraft systems. The hydraulic pressurization systems that use bleed air to pressurize the reservoir use dual check-valves to prevent back-flow of hydraulic fluid into the bleed air. In the rare case of a dual check-valve failure, hydraulic fluid could enter the bleed air system. This cannot occur in the B787 because it does not use a bleed air system. During taxi line-up, aircraft ingest exhaust from other aircraft, and TCP is present in aircraft engine exhaust ${ }^{89,119}$.

Table 8 provides a summary of the SVOCs that were detected. They are grouped by the 
measurements performed on the aircraft either in which there was a subjective perception of smell in the cabin, and technical cabin air contamination (TCAC) flights ${ }^{89}$, which were attributed to oil entry from leaking engine seals in individual flight phases. Smell-events were documented in nine studies ${ }^{60,62,66,69-72,80,86}$ but the smell events could happen not only because of SVOCs. A total of 36 SVOCs were measured, and their concentrations were from below the Limit of Detection (LOD) to $49 \mu \mathrm{g} / \mathrm{m}^{3}$. The SVOCs with high concentrations and high frequency of detection were naphthalene (average concentration $1,241 \pm 166 \mathrm{ng} / \mathrm{m}^{3}$ ), tributyl phosphate (TiBP) (average concentration $495 \pm 59 \mathrm{ng} / \mathrm{m}^{3}$ ), tris (chloro-isopropyl) phosphate (TCPP) (average concentration $506 \pm 0.4 \mathrm{ng} / \mathrm{m}^{3}$ ) and trichloroethylene (TCE) (average concentration $483 \pm 36 \mathrm{ng} / \mathrm{m}^{3}$ ); it is worth mentioning that tributyl phosphate (TiBP) was also detected on discarded cabin air filters at $1 \mathrm{mg} / \mathrm{g}$ carbon for filters that had been used for 660 flight hours and at 2 $\mathrm{mg} / \mathrm{g}$ carbon for filters that had been used for 3,937 flight hours ${ }^{101}$. TMPP was not detected, while TOCP concentrations ranged from 0 to $22,800 \mathrm{ng} / \mathrm{m}^{3}$ with an average of $50 \pm 14 \mathrm{ng} / \mathrm{m}^{3}$; in the study by Schuchardt et al. ${ }^{89}$, TOCP was below LOD.

Among SVOCs for which there were regulations, maximum levels of phosphate cresol mixture and dioctyl sebacate were stipulated in AP- $25^{40}$, but they were not measured in the studies included in the present review. Generally, Table 8 also shows that the concentration of SVOCs measured in aircraft cabins with and without events were lower than the statutory limits for the same compounds in buildings. 
Table 8 Examples of Indoor Air Guideline Values (IAGVs) for SVOCs proposed by WHO, US and in various countries.

\begin{tabular}{|c|c|c|c|c|c|c|c|c|c|c|c|c|c|c|}
\hline \multirow{3}{*}{ Compounds } & \multirow{3}{*}{$\begin{array}{l}\text { Chemical } \\
\text { Abstract } \\
\text { System } \\
\text { (CAS) no. }\end{array}$} & \multicolumn{6}{|c|}{ No events } & \multicolumn{6}{|c|}{ With events } & \multirow{3}{*}{ Relevant regulations and guidelines } \\
\hline & & \multicolumn{4}{|c|}{ Concentration $\left(\mathrm{ng} / \mathrm{m}^{3}\right)$} & \multicolumn{2}{|c|}{ Number of } & \multicolumn{4}{|c|}{ Concentration $\left(\mathrm{ng} / \mathrm{m}^{3}\right)$} & \multicolumn{2}{|c|}{ Number of } & \\
\hline & & Avg. & SD & Min. & Max. & Study & Flight & Avg. & SD & Min. & Max. & Study & Flight & \\
\hline $\begin{array}{c}\text { Tri-ortho-cresyl } \\
\text { phosphate/ } \\
\text { Tri-o-cresyl } \\
\text { Phosphate } \\
\text { (TOCP) }\end{array}$ & $78-30-8$ & 50 & 14 & 0 & 22800 & 4 & 163 & $<L O D$ & - & - & - & 1 & 177 & $\begin{array}{c}0.1 \mathrm{mg} / \mathrm{m}^{3}[\mathrm{skin}]^{111} \\
0.1 \mathrm{mg} / \mathrm{m}^{3} 8 \mathrm{~h}^{110}\end{array}$ \\
\hline $\begin{array}{c}\text { Tributyl phosphate } \\
\text { (TiBP) }\end{array}$ & $126-73-8$ & 495 & 59 & 37 & 9100 & 2 & 149 & 625 & 5.4 & 140 & 1990 & 2 & 194 & $\begin{array}{c}11 \mathrm{mg} / \mathrm{m}^{3} 120 \\
2.38 \mathrm{mg} / \mathrm{m}^{3} 8 \mathrm{~h}^{110}\end{array}$ \\
\hline $\begin{array}{l}\text { Tricresyl } \\
\text { phosphates } \\
\text { (TCP) }\end{array}$ & $1330-78-5$ & 35 & 7.7 & 0.3 & 14900 & 4 & 90 & - & - & - & - & - & - & $0.1 \mathrm{mg} / \mathrm{m}^{3}$ [skin] ${ }^{111}$ \\
\hline Naphthalene & $91-20-3$ & 1241 & 166 & 0 & 49100 & 3 & 83 & - & - & - & - & - & - & $\begin{array}{c}9 \mu \mathrm{g} / \mathrm{m}^{3} \mathrm{C}^{93} \\
10 \mu \mathrm{g} / \mathrm{m}^{3} 1 \text { year }{ }^{94,108} \\
2 \mathrm{mg} / \mathrm{m}^{3}{ }^{120} \\
57.8 \mathrm{mg} / \mathrm{m}^{3} 8 \mathrm{~h}^{110} \\
85.7 \mathrm{mg} / \mathrm{m}^{3} 15 \mathrm{~min}^{110}\end{array}$ \\
\hline $\begin{array}{c}\text { Trichloroethylene } \\
\text { (TCE) }\end{array}$ & 79-01-6 & 483 & 36 & 0 & 20100 & 1 & 80 & - & - & - & - & - & - & $\begin{array}{c}537 \mathrm{mg} / \mathrm{m}^{3} 8 \mathrm{~h}^{111} \\
53.7 \mathrm{mg} / \mathrm{m}^{3} 8 \mathrm{~h}^{110} \\
134 \mathrm{mg} / \mathrm{m}^{3} 15 \mathrm{~min}^{110}\end{array}$ \\
\hline $\begin{array}{c}\text { Triisobutyl } \\
\text { phosphate (TBP) }\end{array}$ & $126-71-6$ & 92 & 9.3 & 3 & 1610 & 1 & 69 & 80 & 0.7 & 7 & 220 & 2 & 194 & $50 \mathrm{mg} / \mathrm{m}^{3} 120$ \\
\hline $\begin{array}{l}\text { Tris (chloroethyl) } \\
\text { phosphate } \\
\text { (TCEP) }\end{array}$ & $115-96-8$ & 15 & 1.0 & 1 & 324 & 1 & 69 & 28 & 1.5 & 0 & 70 & 2 & 194 & $\begin{array}{l}0.05 \mathrm{mg} / \mathrm{m}^{3} 109 \\
0.005 \mathrm{mg} / \mathrm{m}^{3} 109\end{array}$ \\
\hline $\begin{array}{l}\text { Tris (chloro- } \\
\text { isopropyl) } \\
\text { phosphate (TCPP) }\end{array}$ & $13674-84-5$ & 506 & 0.4 & 23 & 9977 & 1 & 69 & 432 & 20 & 0 & 400 & 2 & 194 & 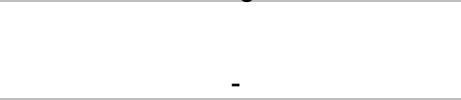 \\
\hline $\begin{array}{l}\text { Tris (1,3-dichloro- } \\
\text { isopropyl) }\end{array}$ & $13674-87-8$ & 7.7 & 0.3 & 1 & 49 & 1 & 69 & 10 & 0.5 & 0 & 10 & 2 & 194 & - \\
\hline
\end{tabular}




\begin{tabular}{|c|c|c|c|c|c|c|c|c|c|c|c|c|c|c|}
\hline $\begin{array}{l}\text { phosphate } \\
\text { (TDCPP) }\end{array}$ & & & & & & & & & & & & & & \\
\hline $\begin{array}{c}\text { Triphenyl } \\
\text { phosphate (TPP) }\end{array}$ & $115-86-6$ & 8.7 & 0.3 & 1 & 119 & 1 & 69 & 14 & 1.0 & 11 & 56 & 2 & 194 & $3 \mathrm{mg} / \mathrm{m}^{3} 8 \mathrm{~h}^{110,111}$ \\
\hline $\begin{array}{l}\text { Tris (butoxy-ethyl) } \\
\text { phosphate } \\
\text { (TBEP) }\end{array}$ & $78-51-3$ & 71 & 4.4 & 0 & 642 & 1 & 69 & 249 & 69 & 29 & 2370 & 2 & 194 & 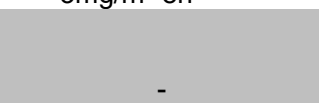 \\
\hline $\begin{array}{l}\text { Diphenyl-2- } \\
\text { ethylhexyl } \\
\text { phosphate } \\
\text { (DPEHP) }\end{array}$ & $1241-94-7$ & 15 & 0.2 & 0 & 282 & 1 & 69 & 20 & 0.7 & 2 & 155 & 2 & 194 & - \\
\hline $\begin{array}{l}\text { Tris (ethyl-hexyl) } \\
\text { phosphate } \\
\text { (TEHP) }\end{array}$ & $78-42-2$ & $<$ LOD & - & 0 & 88 & 1 & 69 & 11 & 0.0 & 1 & 25 & 2 & 194 & - \\
\hline $\begin{array}{l}\text { Tri-m-cresyl } \\
\text { phosphate } \\
(\mathrm{T}-\mathrm{m}-\mathrm{CP})\end{array}$ & $563-04-2$ & 4.4 & 0.3 & 1 & 428 & 1 & 69 & 7.5 & 0.4 & - & - & 1 & 177 & - \\
\hline $\begin{array}{c}\text { Tri-mmp-cresyl } \\
\text { phosphate } \\
\text { (T-mmp-CP) }\end{array}$ & NO & 6.5 & 0.4 & 1 & 691 & 1 & 69 & 9.7 & 0.6 & - & - & 1 & 177 & - \\
\hline $\begin{array}{l}\text { Tri-mpp-cresyl } \\
\text { phosphate } \\
\text { (T-mpp-CP) }\end{array}$ & NO & 4.2 & 0.2 & 1 & 339 & 1 & 69 & 6.9 & 0.4 & - & - & 1 & 177 & - \\
\hline $\begin{array}{l}\text { Tri-p-cresyl } \\
\text { phosphate } \\
\text { (T-p-CP) }\end{array}$ & $563-04-2$ & 2.1 & 0.1 & 1 & 57 & 1 & 69 & 2.9 & 0.2 & - & - & 1 & 177 & - \\
\hline $\begin{array}{l}\text { Trixylyl phosphate } \\
\text { (TXP) }\end{array}$ & NO & $<$ LOD & - & $<$ LOD & $<$ LOD & 1 & 69 & 35 & 0.3 & - & - & 2 & 194 & - \\
\hline Acenaphthylene & $208-96-8$ & 0.8 & 0.6 & 2.6 & 3.3 & 2 & 14 & - & - & - & - & - & - & - \\
\hline Acenaphthene & $83-32-9$ & 5.7 & 4.7 & 17 & 24 & 2 & 14 & - & - & - & - & - & - & - \\
\hline Fluorene & 86-73-7 & 3.0 & 2.2 & 8.8 & 12 & 2 & 14 & - & - & - & - & - & - & - \\
\hline $\begin{array}{c}\text { Hexachlorobenzen } \\
\mathrm{e}\end{array}$ & $118-74-1$ & 0.2 & 0.2 & 0.4 & 2.3 & 2 & 14 & - & - & - & - & - & - & $0.002 \mathrm{mg} / \mathrm{m}^{3} 8 \mathrm{~h}^{110}$ \\
\hline Phenanthrene & $85-01-8$ & 4.9 & 3.7 & 13 & 21 & 2 & 14 & - & - & - & - & - & - & $\begin{array}{l}0.1 \mathrm{mg} / \mathrm{m}^{3} \text { NIOSH } 8 \mathrm{~h}^{111} \\
0.2 \mathrm{mg} / \mathrm{m}^{3} \text { OSHA } 8 \mathrm{~h}^{111}\end{array}$ \\
\hline Anthracene & $120-12-7$ & 0.3 & 0.2 & 0.8 & 1.1 & 2 & 14 & - & - & - & - & - & - & $\begin{array}{l}0.1 \mathrm{mg} / \mathrm{m}^{3} \text { NIOSH } 8 \mathrm{~h}{ }^{111} \\
0.2 \mathrm{mg} / \mathrm{m}^{3} \text { OSHA } 8 \mathrm{~h}\end{array}$ \\
\hline $\begin{array}{l}\text { Trimethylolpropan } \\
\text { e phosphate } \\
\text { (TMPP) }\end{array}$ & $1005-93-2$ & 0 & - & - & - & 1 & 10 & - & - & - & - & - & - & - \\
\hline Fluoranthene & $206-44-0$ & 0.5 & 0.4 & 0.0 & 1.9 & 2 & 14 & - & - & - & - & - & - & - \\
\hline
\end{tabular}




\begin{tabular}{|c|c|c|c|c|c|c|c|c|c|c|c|c|c|c|}
\hline Pyrene & $129-00-0$ & 2.6 & 1.9 & 3.6 & 15 & 2 & 14 & - & - & - & - & - & - & $\begin{array}{l}0.1 \mathrm{mg} / \mathrm{m}^{3} \mathrm{NIOSH} 8 \mathrm{~h}^{111} \\
0.2 \mathrm{mg} / \mathrm{m}^{3} \text { OSHA } 8 \mathrm{~h}^{111}\end{array}$ \\
\hline $\begin{array}{c}\text { Tri-n-butyl } \\
\text { phosphate } \\
\text { (TnBP) }\end{array}$ & NO & 330 & 421 & 20 & 4100 & 1 & 6 & - & - & - & - & - & - & - \\
\hline Retene & $483-65-8$ & 1.4 & - & 0.8 & 2.0 & 1 & 4 & - & - & - & - & - & - & - \\
\hline cis-Permethrin & 61949-76-6 & 0.9 & - & ND & 0.9 & 1 & 4 & - & - & - & - & - & - & - \\
\hline trans-Permethrin & $61949-77-7$ & 1.5 & - & 1.1 & 2.0 & 1 & 4 & - & - & - & - & - & - & - \\
\hline $\begin{array}{l}\text { Seven other PAH } \\
\text { compounds }\end{array}$ & NO & $\begin{array}{c}0.9- \\
10.5\end{array}$ & - & - & - & 1 & 4 & - & - & - & - & - & - & - \\
\hline $\begin{array}{c}2,5- \\
\text { Diphenylbenzoqui } \\
\text { none }\end{array}$ & $844-51-9$ & $<2100$ & - & NR & NR & 1 & 1 & - & - & - & - & - & - & - \\
\hline Dioctyl phthalate & $\begin{array}{c}117-81- \\
7 / 68515-43- \\
5 / 8031-29-6\end{array}$ & 1300 & - & $\mathrm{NR}$ & NR & 1 & 1 & - & - & - & - & - & - & \\
\hline $\begin{array}{c}\text { Tertiary } \\
\text { butylphenol }\end{array}$ & $\begin{array}{c}\text { 88-18- } \\
\text { 6/27178-34- } \\
3\end{array}$ & $<2100$ & - & $N R$ & NR & 1 & 1 & - & - & - & - & - & - & - \\
\hline $\begin{array}{c}\text { Trimethylpentylph } \\
\text { enol }\end{array}$ & NO & $<2100$ & - & NR & NR & 1 & 1 & - & - & - & - & - & - & - \\
\hline
\end{tabular}

NR: not reported.

- ND: not detected.

- $\mathrm{C}=$ chronic. Chronic RELs are designed to address continuous exposures for up to a lifetime: the exposure metric used is the annual average exposure. 


\subsection{Other contaminants and $\mathrm{O}_{3}$}

Table S13 in the SI lists the average concentrations of other contaminants and the ranges of concentration measured in aircraft cabins, together with their maximum recommended levels in regulations and guidelines. These contaminants are: $\mathrm{CO}, \mathrm{NO}$, $\mathrm{NO}_{2}, \mathrm{NO}_{\mathrm{X}}, \mathrm{SO}_{2}$, bacteria, fungi, mould, and $\mathrm{PM}$, such as $\mathrm{PM}_{2.5}, \mathrm{PM}_{10}$ and Respirable Suspended Particulates (RSP). The regulations and guidelines apply both to aircraft cabins and buildings. Except for $\mathrm{NO}_{2}$, the average concentrations of other contaminants were lower than the limits set by regulations and guidelines. The average $\mathrm{NO}_{2}$ concentration was $12 \mathrm{ppb}$ which is higher than the recommended maximum of $11 \mathrm{ppb}$ for TWA $24 \mathrm{~h}^{108}$. Bacteria were at intermediate levels and fungi were at a low level. The maximum measured levels of CO concentration were higher than the permissible level for 15-min exposures.

Ozone $\left(\mathrm{O}_{3}\right)$ enters aircraft cabins through the ventilation system. Commercial aircraft typically cruise at an altitude of 18,000 to 41,000 feet $(5,490 \text { to } 12,500 \text { meters })^{63,121,122}$. At these cruising altitudes they are in the troposphere in higher latitudes ${ }^{75}$, where $\mathrm{O}_{3}$ is at concentrations ranging from $25 \mathrm{ppb}$ to $\sim 900 \mathrm{ppb}^{75,123,124}$. After entering the cabin, $\mathrm{O}_{3}$ will decompose on surfaces and may also undergo reactions with other pollutants on surfaces and in the air; the resulting concentration will therefore be lower than in the supply air.

Figure 2 shows the summary of the $\mathrm{O}_{3}$ levels measured on commercial flights in 11 studies. Figure $\mathrm{S} 2$ in $\mathrm{SI}$ shows the changes with time in average $\mathrm{O}_{3}$ concentration reported in different measuring campaigns on non-smoking flights ${ }^{54,63,65,72,76,86}$. 
Reported ozone levels have been decreasing with time, as more attention has been paid to ozone in aircraft cabins. The $\mathrm{O}_{3}$ concentrations were reported to have been corrected to compensate for air pressure changes in three studies ${ }^{62,63,75}$; the other eight studies did not report whether this correction had been applied ${ }^{14,54,57,65,72,76,84,86}$. As so few studies reported that corrections had been made, we did not distinguish between the two groups as we did in the case of measurements of $\mathrm{CO}_{2}$. The reported $\mathrm{O}_{3}$ levels were between 0 and $275 \mathrm{ppb}$. The minimum levels reported were between 0 and $20 \mathrm{ppb}$, with a median minimum $\mathrm{O}_{3}$ concentration of $2 \mathrm{ppb}$ (Figure 2). The maximum levels reported were between 10 and $275 \mathrm{ppb}$ with a median of $108 \mathrm{ppb}$ (Figure 2). The average concentration of $\mathrm{O}_{3}$ reported was $38 \pm 30 \mathrm{ppb}$ (ranging from 6-80ppb), and the median was $33 \mathrm{ppb}$ (Figure 2). With few exceptions, all of the reported levels were below 250 ppb, which is the limit recommended by the documents prescribing acceptable conditions in aircraft ${ }^{10,36-41}$, see Table 1 , but $75 \%$ of the maximum reported concentrations exceeded $100 \mathrm{ppb}^{10,36-41} ; 87.5 \%$ of the reported maximum concentrations and $31 \%$ of the reported average $\mathrm{O}_{3}$ concentrations exceeded $60 \mathrm{ppb}^{39}$ (Figure 2). All mean and minimum reported levels were below 100 ppb (Figure 2). However, average concentration exceeded the recommended levels averaged over 8 hours, which were $20 \mathrm{ppb}^{108}, 50 \mathrm{ppb}^{125}$ and $50 \mathrm{ppb}$ for heavy workloads ${ }^{110}$, and were below the recommended levels in air averaged over an 8 hour working day, which were $100 \mathrm{ppb}^{111}, 80 \mathrm{ppb}$ (acute level) ${ }^{93}, 200 \mathrm{ppb}(2 \text {-hour average })^{110}$, and $100 \mathrm{ppb}$ and $80 \mathrm{ppb}$ for light and moderate workloads ${ }^{110}$. The World Health Organization ${ }^{125}$ defines high levels as $240 \mu \mathrm{g} / \mathrm{m}^{3}$, the interim target as $160 \mu \mathrm{g} / \mathrm{m}^{3}$ and the air quality guideline at 100 $\mu \mathrm{g} / \mathrm{m}^{3}$ for 8 hour exposures (conversion factor to $\mathrm{ppb}$ is ca. 0.5 ). ASHRAE 161-2013 ${ }^{36}$ recommends that in flights on which excessive $\mathrm{O}_{3}$ levels are likely to occur, $\mathrm{O}_{3}$ concentrations should be continuously monitored and $\mathrm{O}_{3}$ converters should be operated 
to remove $\mathrm{O}_{3}$. In view of this recommendation, it is probable that the high reported $\mathrm{O}_{3}$ levels on commercial flights were due to malfunctioning $\mathrm{O}_{3}$ converters.

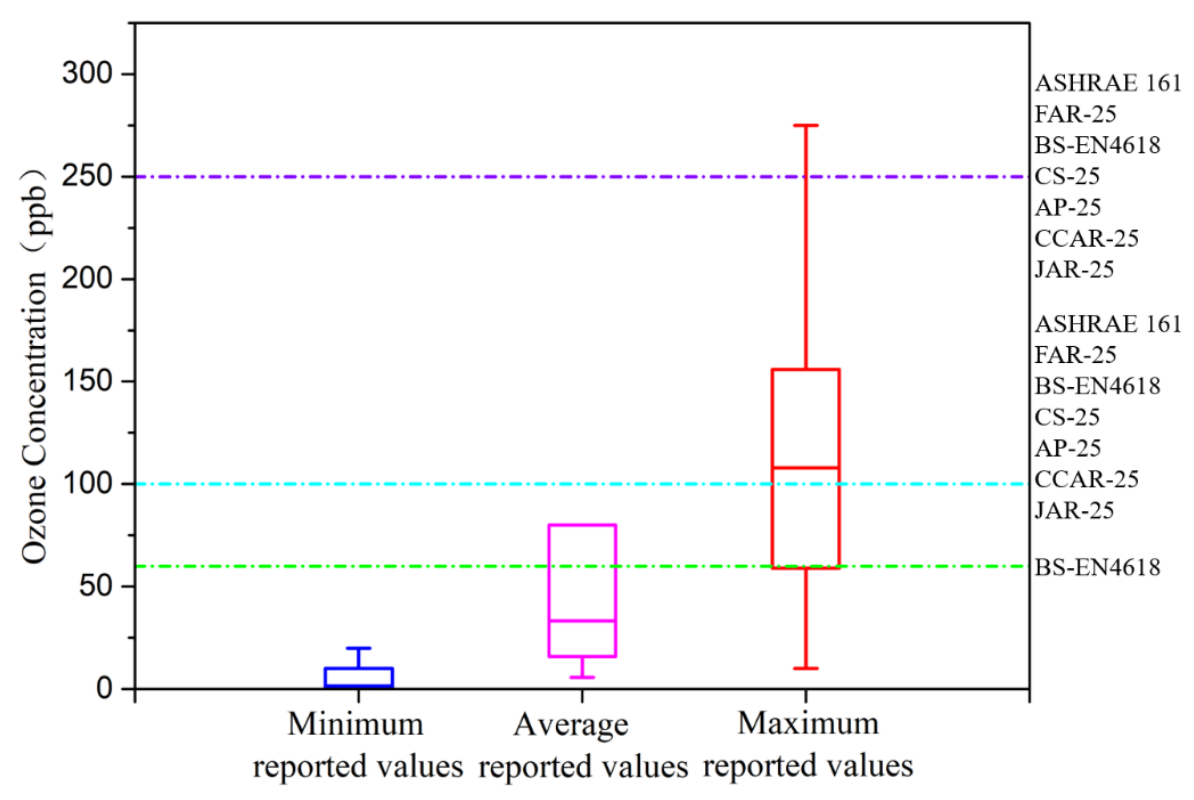

Figure 2 Summary of $\mathrm{O}_{3}$ concentrations measured on non-smoking aircraft in 11 studies 14,54,57,62,63,65,72,75,76,84,86. Permissible levels of $\mathrm{O}_{3}$ prescribed by ASHRAE $161^{36}$, FAR$25^{37}$, JAR- $25^{38}$, BS-EN4618 ${ }^{39}$ (withdrawn), CS- $25^{10}$, AP- $25^{40}$ and CCAR-25 ${ }^{41}$ are also shown.

\subsection{Carbon dioxide and ventilation rate}

Figure 3 shows a summary of carbon dioxide $\left(\mathrm{CO}_{2}\right)$ concentrations measured in 19 studies. The values were automatically or manually corrected to compensate for air pressure changes in seven studies ${ }^{47,54,57,60-62,88}$, and in three studies the instruments used were insensitive to pressure changes in the cabin ${ }^{79,83,90}$. The other nine 
studies ${ }^{14,52,55,56,59,72-74,86}$ did not report whether the reported $\mathrm{CO}_{2}$ concentrations had been compensated for changes in air pressure. The results are consequently divided into two groups: studies that corrected $\mathrm{CO}_{2}$ measurements for changes in pressure and studies that did not state whether this correction was applied. For the former, the minimum measured $\mathrm{CO}_{2}$ concentrations were in the range $410-874 \mathrm{ppm}$, maximum measured $\mathrm{CO}_{2}$ concentrations were in the range $1,485-3,374 \mathrm{ppm}$, while average $\mathrm{CO}_{2}$ concentration was $1,315 \pm 232 \mathrm{ppm}$ (the median was $1,387 \mathrm{ppm}$ ). For the latter, the minimum measured $\mathrm{CO}_{2}$ concentrations were in the range 293-1,100 ppm, the maximum measured $\mathrm{CO}_{2}$ concentrations were in the range between 1,190-5,177 ppm, while the average $\mathrm{CO}_{2}$ concentration was $1,320 \pm 302 \mathrm{ppm}$ (the median was $1,404 \mathrm{ppm}$ ). It can be seen that there were only marginal differences in the measured $\mathrm{CO}_{2}$ between the two groups of studies. The lowest values of minimum measured $\mathrm{CO}_{2}$ concentrations were lower than the $\mathrm{CO}_{2}$ concentration in outdoor air, which currently ranges from 365 ppm to $390 \mathrm{ppm}^{126-129}$, which may suggest some measurement error.

Compared with the aircraft airworthiness standard (Table 1), all measured $\mathrm{CO}_{2}$ concentrations, except for one event, were lower than 5,000 $\mathrm{ppm}^{10,37,39-41}$. All average and minimum $\mathrm{CO}_{2}$ concentrations measured were lower than 2,000 $\mathrm{ppm}^{10,37,39-41}$, although $87 \%$ of average $\mathrm{CO}_{2}$ concentrations were higher than $1,000 \mathrm{ppm}$, which is generally considered as a target for achieving acceptable air quality in occupied buildings ${ }^{130}$.

$\mathrm{CO}_{2}$ is a product of human metabolism and thus indicates the rate of emission of bioeffluents from passengers and cabin crew in aircraft. It is always present in spaces where humans are present. This applies to most commercial buildings and to passenger 
transport vehicles, including aircraft ${ }^{129}$. The concentration of $\mathrm{CO}_{2}$ depends on three factors: number of people, outdoor/ambient air supply rate per person, and ventilation efficiency, i.e., how well the air is mixed within a volume/space ${ }^{88} \mathrm{CO}_{2}$ is an index of ventilation when people are present and can be used to verify whether the recommended rates of outdoor air are being delivered into an aircraft cabin; in this context it is also considered to be a marker of indoor air quality. One study showed that $\mathrm{CO}_{2}$ concentration was significantly and inversely correlated with ventilation rate $(\mathrm{r}=-0.96$, $\mathrm{P}<0.05$ ) for the same aircraft (Airbus 319 ) $^{74}$ and this was also the case in another study that used data from different aircraft (B777, A330, B787, A320, B737, A320) $(\mathrm{r}=-0.93$, $\mathrm{P}<0.05)^{90}$. The potential effects of $\mathrm{CO}_{2}$ on humans are summarized by Fisk et al. ${ }^{131}$ and Du et al. ${ }^{132}$.

The reported outdoor air supply rates ranged from 1.7 to $39.5 \mathrm{~L} / \mathrm{s}$ per person with the average and median at $6.0 \pm 0.8 \mathrm{~L} / \mathrm{s} / \mathrm{p}$ and $5.8 \mathrm{~L} / \mathrm{s} / \mathrm{p}$, respectively ${ }^{47,59,62,72,74,79,83,88,90}$. All of the reported average values exceeded the minimum recommended outdoor air supply rate of $3.5 \mathrm{~L} / \mathrm{s} / \mathrm{p}^{36,37,41}$, and $97 \%$ met the design requirements of $4.7 \mathrm{~L} / \mathrm{s} / \mathrm{p}$ set by ${ }^{10,38} ; 96 \%$ of the reported values met the outdoor air supply rate of $5 \mathrm{~L} / \mathrm{s} / \mathrm{p}$ recommended by the ASHRAE handbook ${ }^{44}$. One study reported the total air change rate per hour $(\mathrm{ACH})^{52}$ that ranged from 17.7 to $27.5 \mathrm{~h}^{-1}$ with an average of $22.6 \pm 4.1 \mathrm{~h}^{-1}$; this was compatible with the air change rates calculated using outdoor air supply $\operatorname{rates}^{52,56,73}$. 


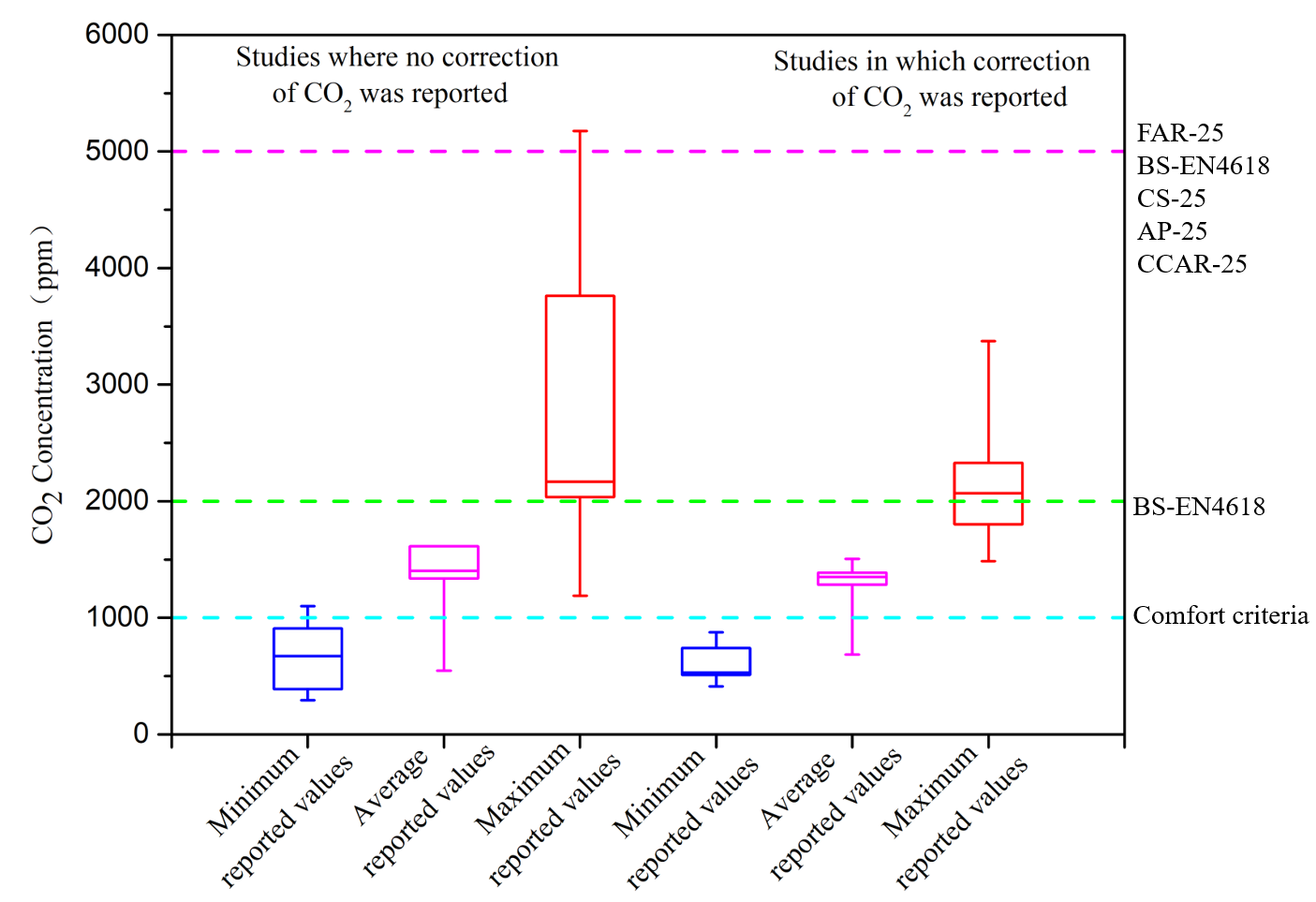

Figure 3 Summary of $\mathrm{CO}_{2}$ concentrations measured on aircraft in 19 studies ${ }^{14,47,52,54-}$ 57,59-62,72-74,79,83,86,88,90. The $\mathrm{CO}_{2}$ limits prescribed by BS-EN4618 ${ }^{39}, \mathrm{FAR}-25^{37}, \mathrm{CS}-25^{10}$, AP- $25^{40}, \mathrm{CCAR}-25^{41}$ and ASHRAE handbook ${ }^{44}$ are also shown.

\subsection{Temperature and relative humidity in aircraft}

Figure 4 shows a summary of the temperatures measured in 14 studies. The minimum measured temperatures were in the range from $17.4^{\circ} \mathrm{C}$ to $24.6^{\circ} \mathrm{C}$. The maximum temperatures were in the range from $25.4^{\circ} \mathrm{C}$ to $31.0^{\circ} \mathrm{C}$. The average and Standard Deviation (SD) of the measured temperatures were $23.5 \pm 0.8^{\circ} \mathrm{C}$; the median was $24.0^{\circ} \mathrm{C}$. The figure shows additionally that average temperatures were almost within the range recommended by ASHRAE $161^{36}$ and the ASHRAE handbook ${ }^{44}$. The results presented in Figure 4 are from all flight phases and it is impossible to separate the measurements reported in different studies based on the flight phase; it is probable that maximum 
reported temperatures were measured on the ground with doors open.

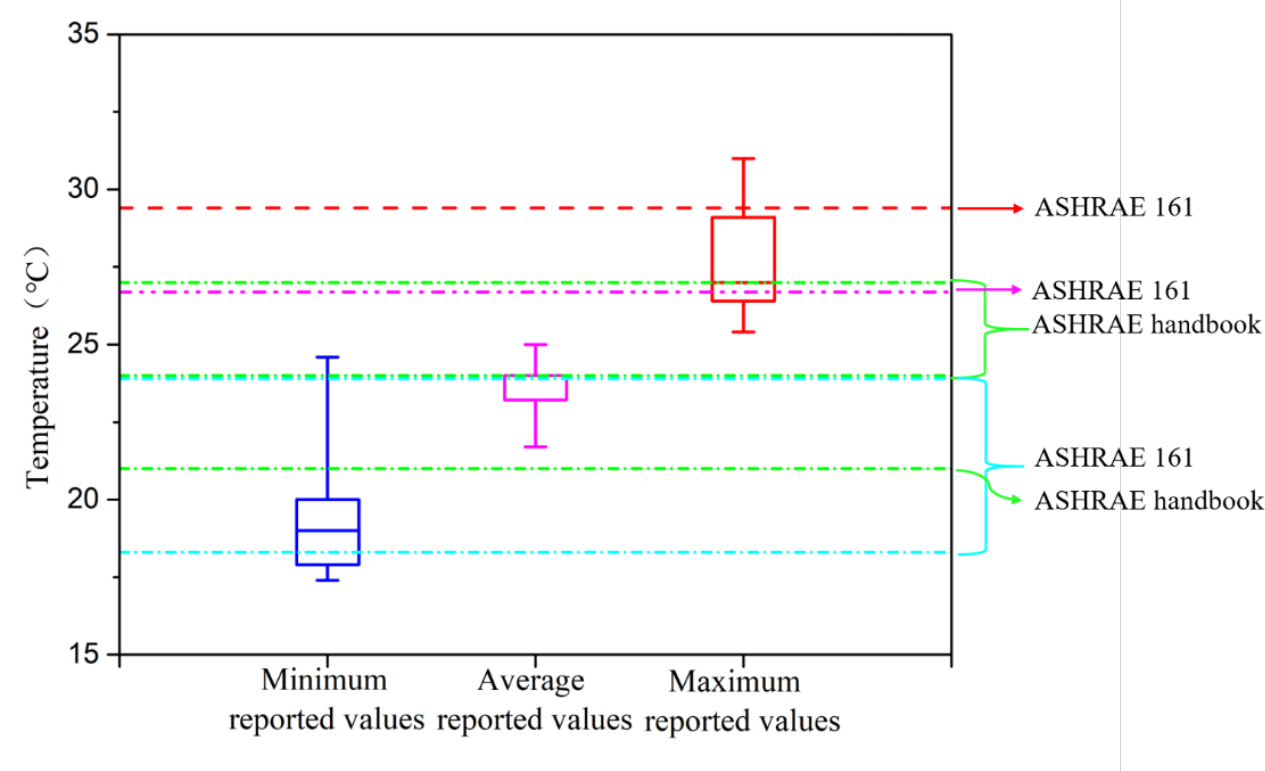

Figure 4 Summary of temperature levels measured on aircraft in 14 studies $6,47,52,54-57,59-$ $62,72,73,86$. The ranges recommended by ASHRAE $161^{36}$ and ASHRAE handbook ${ }^{44}$ are also shown.

Figure 5 shows a summary of the relative humidity $(\mathrm{RH})$ levels measured in 17 studies. The minimum measured $\mathrm{RH}$ levels were in the range from $0.9 \%$ to $15 \%$, the lowest levels representing most likely flights with very few passengers. The maximum measured $\mathrm{RH}$ levels were in the range from $13 \%$ to $77 \%$. The average and SD of the measured RH values were $16 \% \pm 5 \%$; the median was $17 \%$. As in the case of temperature, the results presented in Figure 5 are from all flight phases and it is impossible to separate the measurements reported in different studies according to the flight phase, but it is probable that the maximum levels reported were measured on the ground with doors open and the minimum levels were measured at cruising altitude. The main sources of humidity in an aircraft cabin are exhaled air and perspiration from the occupants. ASHRAE $161^{36}$ does not mandate lower and upper humidity requirements. In buildings, 
ASHRAE $62.1^{130}$ recommends RH should not exceed $65 \%$ and EN 16798-1 133 recommends the range of $\mathrm{RH}$ from 20 to $70 \%$ depending on whether humidification is in operation.

More information on temperature and RH measurements is given in SI. Figures S3 shows that reported average and low humidity level ${ }^{47,52,54,55,57,59-62,72,73,86}$ in aircraft cabins were at the low end of what is measured in buildings located in a cold climate in winter. Figure S4 and Table S14 show among others that at the average temperature and RH levels ${ }^{47,52,54,55,57,59,60,72,86}$ reported in the literature passengers could be from slightly cool to cold at 0.5 clo and from neutral to slightly cool at 1.0 clo, thus below neutral on the cool side of the thermal sensation scale assuming low air velocities; higher air velocities would move these responses further into cool area and considerably increase the risk of draught.

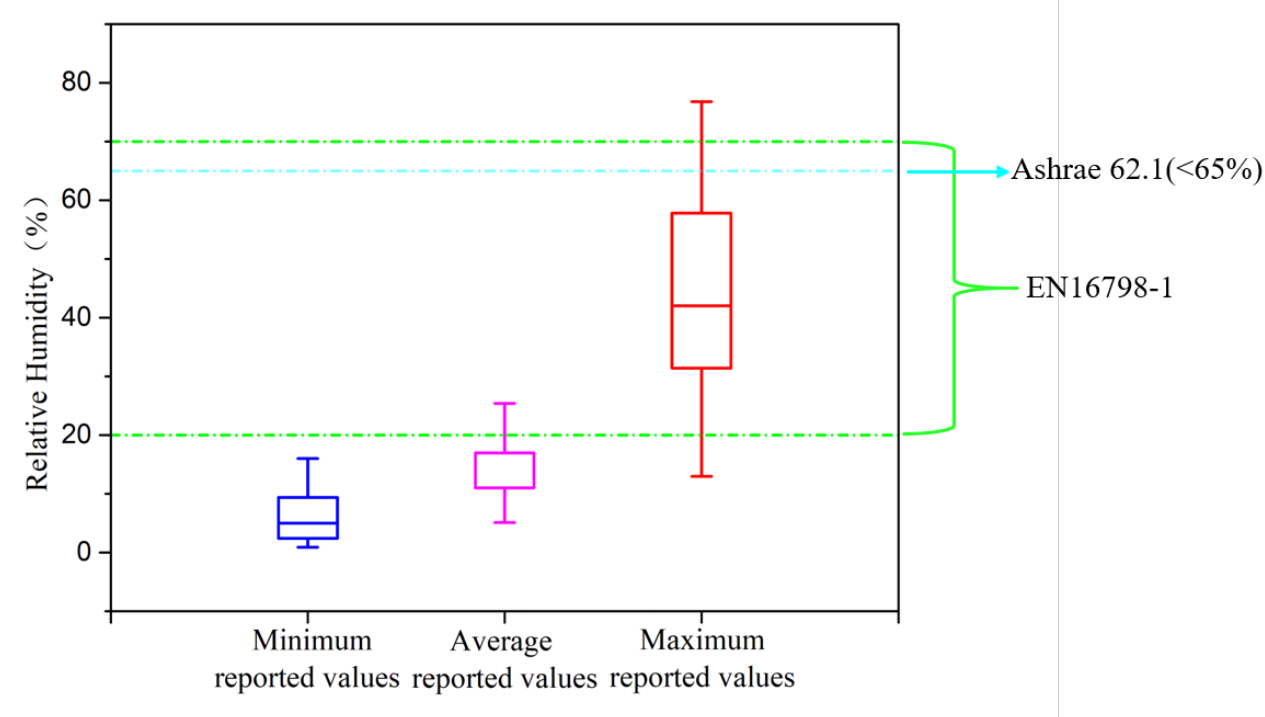

Figure 5 Summary of RH levels measured on aircraft in 17 studies $^{6,47,52,54-62,72-74,86,91}$. The ranges recommended for air-conditioned buildings in ASHRAE $62.1^{130}$ and EN $16798-1^{133}$ are also shown. 


\subsection{Limitations and general comments}

This review summarizes the measurements performed on 2,251 flights. The number of flights is considered to be sufficient for it to be possible to draw reasonable conclusions regarding the air quality conditions on commercial aircraft even though the measurements were made on more than 40 types of aircraft. There was a need for a thorough and data-rich review of cabin air quality to enable broader generalization of the results and definitive conclusions ${ }^{15}$. This work responds to this need.

The VOC and SVOC concentrations we summarize were measured on the non-smoking flights that are typical today. We focused mainly on active sampling and we did not take into account whether it was stated whether an adjustment for cabin pressure had been applied. Applied measuring techniques and QA/QC analysis are presented in detail in Table 9; Table S1 provides information for all types of measurements reported in the present review.

The selection of sampling and analytical methods for VOCs for $25^{6,14,47,53,57,59-62,66,69-}$ $72,75-78,81-86,89$ out of 27 studies $^{6,14,47,53-55,57,59-62,66,69-72,75-78,81-86,89}$ was consistent with the recommendations of American Society of Testing Materials (ASTM) D6399 ${ }^{134}$ among all studies (smoking and non-smoking flights). VOCs sampling and analytical methods for $21^{6,14,57,60,62,66,69-72,75-78,81-86,89}$ out of 22 studies ${ }^{6,14,54,57,60,62,66,69-72,75-78,81-86,89}$ on the non-smoking flights was consistent with the recommendations of ASTM D6399 ${ }^{134}$. One study ${ }^{54}$ was consistent with the recommendations of NIOSH Method (VOCs) ${ }^{135}$ and the Environmental Protection Agency (EPA) method TO11-A ${ }^{136}$ (formaldehyde and 
acrolein). ASTM guidance was not available at the time reported by Nagda and Rector ${ }^{15}$. Fifteen studies $6,57,60,62,66,70-72,76-78,81,82,84,85$ employed field blanks to characterize any contamination of samples during physical handling and eleven studies ${ }^{57,60,69-72,75-78,84}$ used duplicates to characterize precision among 22 studies on the non-smoking flights; only one study ${ }^{60}$ reported the quality control results.

The selection of sampling and analytical methods for SVOCs in four ${ }^{6,14,86,89}$ out of twelve studies $6,14,60,62,66,69-72,80,86,89$ was consistent with the ASTM D6399 method for all studies (smoking and non-smoking flights). SVOCs sampling and analytical methods for four ${ }^{6,14,86,89}$ out of eleven studies ${ }^{6,14,60,62,66,69-72,86,89}$ on the non-smoking flights was consistent with the recommendations of ASTM D $6399^{134}$. One studies ${ }^{60}$ was consistent with the recommendations of EPA Standard Method TO-11A ${ }^{136}$. Two studies ${ }^{70,71}$ was consistent with the recommendations of ISO $16000-6^{137}$ and BS EN ISO $16017-1^{138}$. Four studies ${ }^{62,66,69,72}$ was not reported which standard they reference. Seven studies $^{6,60,62,66,70-72}$ employed field blanks to characterize any contamination of samples during physical handling and five studies ${ }^{60,69-72}$ used duplicates to characterize precision among eleven studies on the non-smoking flights. Only one study ${ }^{60}$ reported the quality control results. 
Table 9 Description of measuring techniques and QA/QC analysis for VOCs and SVOCs.

\begin{tabular}{|c|c|c|c|}
\hline Study & Parameter* & VOCs & SVOCs \\
\hline \multirow[t]{3}{*}{ Dechow et al. ${ }^{53}$} & MT & $\begin{array}{c}\text { Aldehydes and ketones: } \\
\text { TX/(GCMS/AED)/DNPH/(HPLC/UVD); VOCs: } \\
\text { AC/SE/GC/FID; TX/SE/GC/ECD; TX/SE/GC/MS; } \\
\text { TX/TD/GC/MS } \\
\end{array}$ & \\
\hline & QA/QC & A (VOCs and aldehydes) & \\
\hline & $\mathrm{C}$ & & \\
\hline \multirow{3}{*}{ ASHRAE $^{54}$} & MT & $\begin{array}{l}\text { VOCs: NIOSH Method, CL, TX/GC/FID; Formaldehyde, } \\
\text { acrolein: EPA method TO11-A, DNPH/HPLC }\end{array}$ & \\
\hline & QA/QC & B (VOCs and aldehydes) & \\
\hline & $\mathrm{C}$ & NR & \\
\hline \multirow{3}{*}{ Lee et al. ${ }^{55}$} & MT & FID by Total Hydrocarbon Analyzer & \\
\hline & QA/QC & ASTM, ACGIH, APHA, NIOSH, D & \\
\hline & $\mathrm{C}$ & & \\
\hline \multirow{4}{*}{ Fox ${ }^{6}$} & MT & $\begin{array}{c}\text { Aldehydes and ketones: DNPH/HPLC; VOCs: } \\
\text { EC/GC/MS }\end{array}$ & PUF/XAD/GC/MS \\
\hline & $\mathrm{FC}$ & & MM \\
\hline & QA/QC & $A, B$ & $A, B$ \\
\hline & C & & \\
\hline \multirow{3}{*}{ Dumyahn et al. ${ }^{57}$} & MT & $\mathrm{EC} / \mathrm{GC} / \mathrm{MS}$ & \\
\hline & QA/QC & $A, B, D$ & \\
\hline & $\mathrm{C}$ & & \\
\hline \multirow{3}{*}{ Wieslander et al. ${ }^{59}$} & MT & VOCs: TX/GCMS; Formaldehyde: DNPH/HPLC; & \\
\hline & QA/QC & A & \\
\hline & $\mathrm{C}$ & & \\
\hline \multirow{3}{*}{ Nagda et al. ${ }^{60}$} & MT & $\begin{array}{c}\text { Aldehydes and Ketones: EPA Standard Method TO- } \\
\text { 11A, DNPH/HPLC; VOCs: EPA Standard Method TO- } \\
\text { 14A, EC/GCMS }\end{array}$ & $\begin{array}{l}\text { EPA Standard } \\
\text { Method TO-11A, } \\
\text { PUF/XAD/HPLC } \\
\end{array}$ \\
\hline & QA/QC & A, B, D (VOCs and aldehydes) & $\mathrm{B}, \mathrm{D}$ \\
\hline & $\mathrm{C}$ & M & M \\
\hline \multirow{3}{*}{$\begin{array}{l}\text { Lindgren and } \\
\text { Norbäck }^{47}\end{array}$} & MT & $\begin{array}{c}\text { Formaldehyde: glass fiber filters impregnated with } \\
\text { DNPH, the diffusive samplers/GCMS }\end{array}$ & \\
\hline & QA/QC & A & \\
\hline & $\mathrm{C}$ & & \\
\hline \multirow[t]{3}{*}{ Waters et al. ${ }^{61}$} & MT & $\begin{array}{l}\text { VOCs: NIOSH Manual of Analytical Methods,TD/GCMS; } \\
\text { Aldehydes: NIOSH Manual of Analytical Methods, } \\
\text { CPP/GC/FID/MS; Ethanol: NMAM 1400, CL/GC-FID; } \\
\text { Aliphatic hydrocarbons: NMAM 1500, CL/GC-FID; } \\
\text { Aromatic hydrocarbons: NMAM 1501, CL/GC-FID } \\
\end{array}$ & \\
\hline & QA/QC & A & \\
\hline & $\mathrm{C}$ & & \\
\hline \multirow{4}{*}{ Spicer et al. ${ }^{62}$} & MT & Passive Sampling; EC (cruise and bleed)/GCMS & $\begin{array}{c}\text { A time-integrated } \\
\text { adsorbent } \\
\text { sample/XAD/GCMS }\end{array}$ \\
\hline & $\mathrm{FC}$ & MM & MM \\
\hline & QA/QC & $A, B$ & $\mathrm{~B}$ \\
\hline & C & M & $\mathrm{M}, \mathrm{PC}$ \\
\hline Muir et al. ${ }^{66}$ & MT & TD/GCMS; SPME/GCMS; PID (fume event) & $\begin{array}{c}\text { TD/GCMS; } \\
\text { SPME/GCMS; PID } \\
\text { (fume event) } \\
\end{array}$ \\
\hline
\end{tabular}




\begin{tabular}{|c|c|c|c|}
\hline & QA/QC & $A, B$ & B \\
\hline & C & & \\
\hline \multirow{3}{*}{ Solbu et al. ${ }^{69}$} & MT & TX/TD/GC-EI-MS & $\begin{array}{l}\text { Gass adsorbent } \\
\text { tube/GC-EI-MS }\end{array}$ \\
\hline & QA/QC & $A, D$ & $\mathrm{D}$ \\
\hline & $\mathrm{C}$ & & \\
\hline \multirow[t]{3}{*}{ Crump et al. ${ }^{70}$} & MT & $\begin{array}{c}\text { TVOCs: PID; VOCs: ISO } 16000-6 \text { and BS EN ISO } \\
\text { 16017-1, Sorbent tube/TD/GC/MS }\end{array}$ & $\begin{array}{c}\text { ISO } 16000-6 \text { and BS } \\
\text { EN ISO } 16017-1 \\
\text { Sorbent } \\
\text { tube/TD/GC/MS }\end{array}$ \\
\hline & QA/QC & $A, B, D$ & $\mathrm{~B}, \mathrm{D}$ \\
\hline & $\mathrm{C}$ & & \\
\hline \multirow{3}{*}{ Crump et al. ${ }^{71}$} & MT & $\begin{array}{l}\text { TVOCs: PID; VOCs: ISO } 16000-6 \text { and BS EN ISO } \\
\text { 16017-1 Sorbent tube/TD/GC/MS }\end{array}$ & $\begin{array}{c}\text { ISO } 16000-6 \text { and BS } \\
\text { EN ISO } 16017-1 \\
\text { Sorbent tube } \\
\text { samples/TD/GC/MS }\end{array}$ \\
\hline & QA/QC & $A, B, D$ & $\mathrm{~B}, \mathrm{D}$ \\
\hline & $\mathrm{C}$ & & \\
\hline \multirow[t]{3}{*}{ Spengler et al. ${ }^{72}$} & MT & $\begin{array}{c}\text { VOCs: airlines A: EC/GCMS; airlines B and C: USEPA } \\
\text { Compendium Method TO-17, TD/GCM; Aldehyde and } \\
\text { ketone: airlines A, B and C: DNPH/HPLC }\end{array}$ & $\begin{array}{c}\text { TCP: Whatman QMA } \\
37 \text { mm quartz } \\
\text { filters/SE/GCMS; } \\
\text { SVOCs: SKC model } \\
226-143 \text { glass } \\
\text { sorbent } \\
\text { tubes/XAD/SE/GCMS }\end{array}$ \\
\hline & QA/QC & $A, B, D$ & $B, D$ \\
\hline & $\mathrm{C}$ & & \\
\hline \multirow{3}{*}{ Weisel et al. ${ }^{75}$} & MT & $\mathrm{TX} / \mathrm{GC} / \mathrm{MS}$ & \\
\hline & QA/QC & $A, D$ & \\
\hline & $\mathrm{C}$ & $\mathrm{C}$ & \\
\hline \multirow{3}{*}{$\mathrm{Ji}$ and $\mathrm{Zhao}{ }^{76}$} & MT & TX/TD/GC/MS & \\
\hline & QA/QC & $A, B, D$ & \\
\hline & $\mathrm{C}$ & $\mathrm{PC}$ & \\
\hline \multirow{3}{*}{ Guan et al. ${ }^{77}$} & MT & TX/TD/GC/MS & \\
\hline & QA/QC & $A, B, D$ & \\
\hline & C & & \\
\hline \multirow{3}{*}{ Guan et al. ${ }^{78}$} & MT & $\mathrm{TX} / \mathrm{TD} / \mathrm{GC} / \mathrm{MS}$ & \\
\hline & QA/QC & $A, B, D$ & \\
\hline & $\mathrm{C}$ & & \\
\hline \multirow{3}{*}{ Ree et al. ${ }^{80}$} & MT & & Wipe samples/GCMS \\
\hline & QA/QC & & \\
\hline & C & & \\
\hline \multirow{3}{*}{ Wang et al. ${ }^{81}$} & MT & EPA, TX/TD/GCMS & \\
\hline & QA/QC & $A, B$ & \\
\hline & $\mathrm{C}$ & $\mathrm{M}$ & \\
\hline \multirow{3}{*}{ Wang et al. ${ }^{82}$} & MT & EPA, TX/TD/GCMS & \\
\hline & QA/QC & $A, B$ & \\
\hline & $\mathrm{C}$ & $M$ & \\
\hline \multirow{3}{*}{ Guan et al..$^{83}$} & MT & TVOCs: a ppbRAE 3000-PID & \\
\hline & QA/QC & $A$ & \\
\hline & C & NSP & \\
\hline
\end{tabular}




\begin{tabular}{|c|c|c|c|}
\hline \multirow{3}{*}{ Gao et al. ${ }^{84}$} & MT & TX/TD/GC/MS & \\
\hline & QA/QC & $A, B, D$ & \\
\hline & $\mathrm{C}$ & $\mathrm{C}$ & \\
\hline \multirow{4}{*}{ Rosenberger et al. ${ }^{85}$} & MT & Aldehydes: DNPH/HPLC-UV & \\
\hline & FC & MM & \\
\hline & QA/QC & $A, B$ & \\
\hline & C & & \\
\hline \multirow{3}{*}{ Schuchardt et al. ${ }^{86}$} & MT & $\begin{array}{l}\text { Aldehydes: DIN ISO 16000-3, DNPH/HPLC/UV; VOCs: } \\
\text { DIN ISO 16000-6-TX/MS/FID }\end{array}$ & $\begin{array}{l}\text { ISO } 16000-31 / 2014 \\
\text { Indoor air - Part } 31 \text {, } \\
\text { PUR/SE/GCMS }\end{array}$ \\
\hline & QA/QC & A & $\mathrm{A}$ \\
\hline & $\mathrm{C}$ & $\mathrm{C}$ & $\mathrm{C}$ \\
\hline \multirow{3}{*}{ Rosenberger ${ }^{14}$} & MT & $\begin{array}{l}\text { VOCs: TX/TD/GCMS; Aldehydes: DNPH/HPLC/UV/VIS; } \\
\text { TVOCs: PID }\end{array}$ & PUR/GCMS \\
\hline & QA/QC & A, ISO 16000 series, $D$ & A, ISO 16000 series \\
\hline & C & & \\
\hline \multirow{3}{*}{ Schuchardt et al. ${ }^{89}$} & MT & $\begin{array}{l}\text { VOCs: ISO 16000-3/2011 Indoor air - Part 6, } \\
\text { TX/TD/GC/MS or MS-FID. Aldehydes: ISO 16000- } \\
\text { 3/2011 Indoor air - Part 3, DNPH/HPLC/UV } \\
\end{array}$ & $\begin{array}{l}\text { TCP:ISO 16000-31, } \\
\text { 2014-Part 31, } \\
\text { PUR/SE/GC/MS } \\
\end{array}$ \\
\hline & $\mathrm{FC}$ & MM & \\
\hline & QA/QC & A, ISO 16000-6: 2011 & A, ISO 16000-6: 2011 \\
\hline
\end{tabular}

* MT-measuring technique (AC, activated carbon sorbent; CL, a charcoal sorbent tube; DNPH, 2,4-

dinitrophenylhydrazine-coated sorbent; EC, evacuated canister; ECD, electron capture detector; FID, flame ionization detector; GC, gas chromatography; HPLC, high performance liquid chromatography; AED, atomic-emission detector; UVD, UV-detector; MM, mass flowmeter; MS, mass spectrometry; PID, photoionization detector; El, electron ionization; IC, Ion Chromatograph; CPP, coated porous polymer; PUF, polyurethane foam sorbent; SE, solvent elution; TD, thermal desorption; TX: Tenex sorbent; SPMF, Solid Phase Microextract Fibres; OPC, optical particle counter; CPC, condensed particle counter; NDIR, Non-dispersive infrared spectrometry; PCR, Polymerase chain reaction technology).

FC-Flow control.

QA/QC-quality assurance/quality control (A, consistent with recommendations of ASTM D6399; B, field blanks; D, duplicate samples)

C-Calibration (M, multipoint calibration; NRC, no pressure calibration; PC, pressure calibration; CSG, calibrated by standard gases; NSP, not sensitive to pressure).

NR - not reported. 
Most measurements of VOCs and SVOCs were performed only once using integrating samplers and the sensors and samplers were positioned in only one location in the cabin. In order to obtain more accurate data, the number of samples should be increased in space and time in future research and a method for real-time monitoring data instead of intermittent sampling should be used.

The quality of the measured data included in the present review can be discussed. With respect to the measurements of temperature and $\mathrm{RH}$ the studies included in the present review included only partial details of the measurement technique, range, resolution, accuracy and whether the instruments were calibrated or not. In general, it was reported that the measuring instruments had good accuracy for temperature measurements ${ }^{54,60,62,72-74}$ and for RH measurements ${ }^{54,60,62,72,73}$.

With respect to $\mathrm{CO}_{2}$ measurements some studies failed to include information on whether a correction for cabin pressure at altitude had been applied. The studies in which no correction for pressure was mentioned used a variety of measuring instruments with an accuracy of about $\pm 3 \%{ }^{72}, \pm 100 \mathrm{ppm} \mathrm{CO}_{2}$ below $10,000 \mathrm{ppm}$ and above $100 \mathrm{ppm}$ or $\pm 3 \%$ at concentrations below $100 \mathrm{ppm}^{73}$. The studies in which correction of $\mathrm{CO}_{2}$ was reported also used a variety of measuring instruments. ASHRAE and CSS ${ }^{54}$ and Spicer et al. ${ }^{62}$ reported measurements using instruments with an accuracy of $\pm 5 \%$. Cao et al. ${ }^{88}$ reported that their $\mathrm{CO}_{2}$ sensor could provide better accuracy for the lower levels more likely to be encountered in aircraft cabins and in their study, $98 \%$ of measured $\mathrm{CO}_{2}$ concentrations were within this range.

We analysed measured $\mathrm{O}_{3}$ data only on non-smoking flights. We did not consider the 
influence of aircraft pressure and altitude on measured concentration as there were very few data. The accuracy of the instruments was greater than $1.0 \mathrm{ppb}$ or $2 \%{ }^{72,75}$ or greater than $1.5 \mathrm{ppb}$ or $2 \%{ }^{62,65}$ although some had an accuracy of $\pm 0.1 \mathrm{ppm}^{54}$.

The present results can be used for different purposes, e.g., to benchmark the air quality levels in aircraft cabins or to select the target compounds that can be considered as markers of air quality and could constitute an air quality metric. This would however require studies with humans that observed their different responses to changing levels of the selected target pollutants. It would be useful to examine whether there is a relationship between measured concentrations of VOCs and carbon dioxide $\left(\mathrm{CO}_{2}\right)$ using the data provided by the literature review. However, the information provided in the reviewed papers was not sufficient to perform such a correlation.

\section{Conclusions}

We reviewed the literature to identify the airborne pollutants present on commercial aircraft and the regulations regarding air quality on aircrafts. The measurements reported by forty-seven studies on 2,251 flights showed that the majority of measured compounds were alcohols followed by aldehydes, alkanes, terpenes, aromatics and ketones. Among the most prevalent compounds reported were toluene, ethylbenzene, benzene, formaldehyde, acetaldehyde, limonene, nonanal, hexanal, decanal, octanal, acetic acid, acetone, ethanol, butanal, acrolein, isoprene and menthol. Measured VOCs were within the permissible limits where they exist, except for benzene. SVOCs were below the limits prescribed for any indoor environment. Average $\mathrm{O}_{3}$ concentrations were below air quality guidelines for aircraft cabins but exceeded air quality guidelines 
for residential buildings or workplaces. Average $\mathrm{CO}_{2}$ and outdoor air supply rates were within recommended levels. Average temperature was within the limits recommended for thermal comfort while RH values were at the low end of what occurs even in buildings located in cold climates in winter. The present results provide a benchmark reference for airborne pollutants on aircraft in the development of advanced solutions for improving cabin air quality. The present work should continue by relating the measured levels to the responses of crew members and passengers to provide further evidence of the need to improve the control of aircraft cabin air quality and to identify the pollutant levels that should be regulated, as well as smell events and proper risk assessment thereof. The impact of other factors such as the low $\mathrm{RH}$ should be considered as well.

\section{Acknowledgements}

This work received funding from the Clean Sky 2 Joint Undertaking under the European Union's Horizon 2020 research and innovation programme under grant agreement No. 820872-ComAir-H2020-CS2-CFP07-2017-02. The grant supported the ComAir project with the title "Investigation of cabin ventilation strategies impact on aircraft cabin air quality and passengers' comfort and well-being through subject study in realistic aircraft environment". The work was also supported by the CognitAir project with the title " $\mathrm{CO}_{2}$ and VOCs requirements for aircraft cabins / occupied spaces based on cognitive performance, comfort responses and physiological changes depending on

pressure level". CognitAir was financially supported by Honeywell, Airbus, Pall, Embraer and Liebherr and was co-funded by ASHRAE. We thank Prof. David P. Wyon for his constructive comments and revisions and Dr. J. Enrique Cometto-Muñiz for his 
advice on odour thresholds. The authors declare no conflict of interest and are responsible for the content of this publication.

\section{References}

1. Mazareanu E. Air transportation - Statistics \& Facts. 2020. https://www.statista.com/topics/1707/airtransportation/.pdf Accessed Mar 4, 2020.

2. Mazareanu E. Global air traffic - scheduled passengers 2004-2020. 2020. https://www.statista.com/statistics/564717/airline-industry-passenger-traffic-globally/.pdf Accessed Jun $10,2020$.

3. Mazareanu E. Commercial airlines worldwide - fuel consumption 2005-2020. 2020. https://www.statista.com/statistics/655057/fuel-consumption-of-airlines-worldwide/.pdf Accessed Jun $10,2020$.

4. Rosero JA, Ortega JA, Aldabas E, Romeral L. Moving Towards a More Electric Aircraft. IEEE A\&E Systems Magazine 2007: 3-9.

5. Aviation. How much air is recirculated (vs. bleed air injected) in modern airliners cabin? 2017. https://aviation.stackexchange.com/questions/43702/how-much-air-is-recirculated-vs-bleed-airinjected-in-modern-airliners-cabin.pdf Accessed 2017.

6. Fox RB. Air quality and comfort measurement aboard a commuter aircraft and solutions to improve perceived occupant comfort levels. In: Nagda, N.L. (ed.) Air Quality and Comfort in Airliner Cabins: ASTM STP 1393. West Conshohocken, PA, American Society for Testing and Materials 2000: 161-186. 7. NRCC. The Airliner Cabin Environment and the Health of Passengers and Crew. Washington (DC): National Academies Press (US); 2002. 344 p.

8. EASA. Certification Specifications and Acceptable Means of Compliance for Large Aeroplanes. 2003. 9. Zavaglio E, Le Cam M, Thibaud C, Quartarone G, Zhu Y, Franzini G, Roux PD, Dinca M, Walte A, Rothe P, (2019) Innovative Environmental Control System for Aircraft, 49th International Conference on Environmental Systems, 7-11 July 2019, Boston, Massachusetts.

10. EASA. CS-25 Certification Specifications and Acceptable Means of Compliance for Large Aeroplanes, Amendment 23. 2019.

11. Newman WH, Viele MR. Engine bleed air reduction in DC-10. 1980.

12. Liu W, Mazumdar S, Zhang Z, Poussou SB, Liu J, Lin C-H, Chen Q. State-of-the-art methods for studying air distributions in commercial airliner cabins. Building and Environment 2012; 47: 5-12.

13. Crump D. Air quality in aircraft: A continuing debate. Indoor and Built Environment 2016; 25: 725 727.

14. Rosenberger W. Effect of charcoal equipped HEPA filters on cabin air quality in aircraft. A case study including smell event related in-flight measurements. Building and Environment 2018; 143: 358-365.

15. Nagda NL, Rector HE. A critical review of reported air concentrations of organic compounds in aircraft cabins. Indoor Air 2003; 13: 292-301.

16. Lindgren T, Norbäck D. Health and perception of cabin air quality among Swedish commercial airline crew. Indoor Air 2005; 15.

17. Ahmadpour N, Lindgaard G, Robert J-M, Pownall B. The thematic structure of passenger comfort experience and its relationship to the context features in the aircraft cabin. Ergonomics 2014; 57: 801815.

18. Harshada P, Mirabelle DC. Passenger-centric factors influencing the experience of aircraft comfort. Transport Reviews 2017; 38: 252-269.

19. Wolkoff P, Crump DR, Harrison PTC. Pollutant exposures and health symptoms in aircrew and office workers: Is there a link? Environment International 2016; 87: 74-84.

20. McNeely E, Gale S, Tager I, Kincl L, Bradley J, Coull B, Hecker S. The self-reported health of U.S. flight attendants compared to the general population. Environ Health 2014; 13: 13.

21. Griffiths RF, Powell DM. The occupational health and safety of flight attendants. Aviat Space Environ Med 2012; 83: 514-521.

22. Nagda NL, Rector HE, Li Z, Space DR. Aircraft Cabin Air Quality A Critical Review of Past Monitoring Studies. ASTM Spec. Tech. Publ. 2000.

23. Space DR, Johnson RA, Rankin WL, Nagda NL. The airplane cabin environment: Past, present and future research. ASTM Spec. Tech. Publ. 2000.

24. Lindgren T. Cabin Air Quality in Commercial Aircraft: Exposure, Symptoms and Signs. 
Comprehensive Summaries of Uppsala Dissertations from the Faculty of Medicine 1262. 2003.

25. FAA. 14 CFR 25, “Code of Federal Regulations," Airworthiness Standards, Title 14, §25, Washington, DC. 1998.

26. ANSI/ASHRAE. ANSI/ASHRAE Standard 62, Ventilation for Acceptable Indoor Air Quality. Atlanta, GA. 1989.

27. Wolkoff P, Nielsen GD. Organic compounds in indoor air-their relevance for perceived indoor air quality? Atmospheric Environment 2001.

28. Norrefeldt V, Mayer F, Herbig B, Ströhlein R, Wargocki P, Fang L. Effect of Increased Cabin Recirculation Airflow Fraction on Relative Humidity, CO2 and TVOC. Aerospace 2021; 8.

29. Jones B, Amiri SN, Roth JW, Hosni M, (2016) The Nature of Particulates in Aircraft Bleed Air Resulting from Oil Contamination.

30. Weisel CP, Fiedler N, Weschler CJ, Ohman-Strickland PA, Mohan KR, McNeil K, Space DR. Human symptom responses to bioeffluents, short-chain carbonyls/acids, and long-chain carbonyls in a simulated aircraft cabin environment. Indoor Air 2017; 27: 1154-1167.

31. Solbu K, Daae HL, Thorud S, Ellingsen DG, Lundanes E, Molander P. Exposure to airborne organophosphates originating from hydraulic and turbine oils among aviation technicians and loaders. J Environ Monit 2010; 12: 2259-2268.

32. van Netten C. Air Quality and Health Effects Associated with the Operation of BAe 146-200 Aircraft. Applied Occupational and Environmental Hygiene 1998; 13: 733-739.

33. van Netten C. Design of a small personal air monitor and its application in aircraft. Sci Total Environ 2009; 407: 1206-1210.

34. Abraham MH, Sanchez-Moreno R, Cometto-Muniz JE, Cain WS. An algorithm for 353 odor detection thresholds in humans. Chem Senses 2012; 37: 207-218.

35. Nagata Y, Takeuchi N. Measurement of Odor Threshold by Triangle Odor Bag Method. Odor Measure Rev. 2003: 118-127.

36. ASHRAE. ANSI/ASHRAE Standard 161-2013, Air Quality within Commercial Aircraft, Atlanta. 2013.

37. FAA. Federal Aviation Regulations (FAR) Part 25 Airworthiness standards: Transport category airplanes, Washington. 2019.

38. JAA. Joint Airworthiness Requirements (Change 15) Part 25 Large Aeroplanes, Cheltenham: Civil Aviation Authority. 2007.

39. ASD-STAN. prEN 4618: 2013 Aerospace series-aircraft internal air quality standards: criteria and determination methods,Brussels: ASD-STAN. 2013.

40. IAC. Aviation Regulations (AP) Part 25 Airworthiness standards for Transport category Airplanes (in Russia). 2005.

41. CCAC. Chinese civil aviation regulations Part 25 airworthiness standards for transport aircraft, Order of CAAC no. 19 of 2016. 2016.

42. Wanner H-U, Verhoeff A, Colombi A, Flannigan B, Gravesen S, Mouileseaux A, Nevalainen A, Papadakis J, Seide K. Biological particles in Indoor Environments. European Collaborative Action, Indoor air quality and its impact on man. Commission of the European Communities, Luxembourg, 1993. 43. EU, BIA. 'Guidelines workplace, Germany' according EU frame-guidelines 89/391; BIA's report 2/95 'Indoor Air Quality', Germany.

44. ASHRAE. ASHRAE Handbook HVAC Applications. 2019.

45. Park MY. These Are the Healthiest Planes in the Sky. 2018. https://thepointsguy.com/news/thehealthiest-planes-in-the-air-today/ Accessed May 7, 2018.

46. Reed T. Twenty-five Years Ago, U.S. Airlines Banned Smoking On Domestic Flights. Aerospace and Defense 2015.

47. Lindgren T, Norbäck D. Cabin air quality indoor pollutants and climate during intercontinental flights with and without tobacco smoking. Indoor Air 2002; 12: 263-272.

48. Brabets RI, Hersh CK, Klein MJ. Ozone measurement survey in commercial jet aircraft. Journal of Aircraft 1967; 4: 59-64.

49. Bischof W. Ozone measurements in jet airliner cabin air. Water, Air, and Soil Pollution 1973; 2: 3-14. 50. Perkins PJ, Holdeman JD, Nastrom GD. Simultaneous Cabin and Ambient Ozone Measurements on Two Boeing 747 Airplanes. 1979.

51. Rogers JW. Results of FAA cabin ozone monitoring program in commercial aircraft in 1978 and 1979. 1980.

52. Nagda NL, Koontz MD, Konheim AG, Hammond SK. Measurement of cabin air quality aboard commercial airliner. Atmospheric Environment 1992; 26: 2203-2210.

53. Dechow M, Sohn H, Steinhanses J. Concentrations of selected contaminants in cabin air of airbus aircrafts. Chemosphere 1997; 35: 21-31. 
54. ASHRAE, CSS. Relate Air Quality and Other Factors to Symptoms Reported by Passengers and Crew on Commercial Transport Category Aircraft. 1999.

55. Lee S-C, Poon C-S, Li X-D, Luk F. Indoor Air Quality Investigation on Commercial Aircraft. Indoor Air 1999; 9: 180-187.

56. Haghighat F, Allard F, Megri AC, Blondeau P, Shimotakahara R. Measurement of thermal comfort and indoor air quality aboard 43 flights on commercial airlines. Indoor and Built and Environment 1999; 8: 58-66.

57. Dumyahn TS, Spengler JD, Burge HA, Muilenburg M. Comparison of the environments of transporation vehicles: results of two surveys. In: Nagda, N.L. (ed.) Air Quality and Comfort in Airliner Cabins: ASTM STP 1393. West Conshohocken, PA, American Society for Testing and Materials 2000: 3-23.

58. Ree dH, Bagshaw M, Simons R, Brown RA. Ozone and relative humidity in airline cabins on polar routes measurements and physical symptoms. ASTM Spec. Tech. Publ. 2000.

59. Wieslander G, Lindgren T, Norback D, Venge P. Changes in the ocular and nasal signs and symptoms of aircrews in relation to the ban on smoking on intercontinental flights. Scand J Work Environ Health 2000; 26: 514-522.

60. Nagda NL, Rector HE, Li Z, Hunt EH. Determine Aircraft Supply Air Contaminants in the Engine Bleed Air Supply System on Commercial Aircraft. 1791 Tullie Circle, NE, Atlanta, GA 30329-2305; 2001.

61. Waters MA, Bloom TF, Grajewski B, Deddens J. Measurements of indoor air quality on commercial transport aircraft. Proceedings: Indoor Air 20022002.

62. Spicer CW, Murphy MJ, Holdren MW, Myers JD, MacGregor IC, Holloman C, James RR, Tucker K, Zaborski R. Relate Air Quality and Other Factors to Comfort and Health Symptoms Reported by Passengers and Crew on Commercial Transport Aircraft (Part I) (ASHRAE Project 1262-TRP). 2004.

63. Spengler JD, Ludwig S, Weker RA. Ozone exposures during trans-continental and trans-pacific flights. Indoor Air 2004; 14: 67-73.

64. Duc ML, Stuecker T, Venkateswaran K. Molecular bacterial diversity and bioburden of commercial airliner cabin air. Canadian Journal of Microbiology 2007; 53: 1259-1271.

65. Bhangar S, Cowlin SC, Singer BC, Sextro RG, Nazaroff WW. Ozone levels in passenger cabins of commercial aircraft on North American and transoceanic. Environmental Science \& Technology 2008; 42: 3938-3943.

66. Muir H, Walton C, Mckeown R. Cabin Air Sampling Study Functionality Test. Cranfield University School of Engineering 2008.

67. McKernan LT, Wallingford KM, Hein MJ, Burge H, Rogers CA, Herrick R. Monitoring microbial populations on wide-body commercial passenger aircraft. Annals of Occupational Hygiene 2008; 52 : 139-149.

68. Osman S, Duc ML, Dekas A, Newcombe D, Venkateswaran K. Microbial burden and diversity of commercial airline cabin air during short and long durations of travel. The ISME Journal 2008; 2: 482497.

69. Solbu K, Daae HL, Olsen R, Thorud S, Ellingsen DG, Lindgren T, Bakke B, Lundanes E, Molander P. Organophosphates in aircraft cabin and cockpit air-method development and measurements of contaminants. Journal of Environmental Monitoring 2011; 13: 1393-1403.

70. Crump D, Harrison P, Walton C. Aircraft Cabin Air Sampling Study; Part 1 of the Final Report. Institute of Environment and Health report 2011.

71. Crump D, Harrison P, Walton C. Aircraft Cabin Air Sampling Study; Part 2 of the Final Report. Institute of Environment and Health report 2011.

72. Spengler JD, Vallarino J, McNeely E, Estephan H. In-Flight/Onboard Monitoring: ACER's Component for ASHRAE 1262, Part 2. Final Report, 2005-2010. 2012.

73. Gładyszewska-Fiedoruk K. Indoor air quality in the cabin of an airliner. Journal of Air Transport Management 2012; 20: 0-30.

74. Giaconia C, Orioli A, Gangi AD. Air quality and relative humidity in commercial aircrafts: An experimental investigation on short-haul domestic flights. Building and Environment 2013; 67: 69-81.

75. Weisel C, Weschler CJ, Mohan K, Vallarino J, Spengler JD. Ozone and Ozone Byproducts in the Cabins of Commercial Aircraft. Environmental Science \& Technology 2013; 47: 4711-4717.

76. Ji W, Zhao B. Estimation of the contribution of secondary organic aerosol to PM2.0 concentration in aircraft cabins. Building and Environment 2014; 82: 267-273.

77. Guan J, Gao K, Wang C, Yang X, Lin C-H, Lu C, Gao P. Measurements of volatile organic compounds in aircraft cabins. Part I: Methodology and detected VOC species in 107 commercial flights. Building and Environment 2014; 72: 154-161.

78. Guan J, Wang C, Gao K, Yang X, Lin C-H, Lu C. Measurements of volatile organic compounds in 
aircraft cabins. Part II: Target list, concentration levels and possible influencing factors. Building and Environment 2014; 75: 170-175.

79. Li Z, Guan J, Yang X, Lin C-H. Source apportionment of airborne particles in commercial aircraft cabin environment: Contributions from outside and inside of cabin. Atmospheric Environment 2014; 89: 119-128.

80. Ree HD, Martin VDB, Brand T, Mulder GJ, Simons R, Brinio VVZ, Westerink RHS. Health risk assessment of exposure to TriCresyl Phosphates (TCPs) in aircraft: a commentary. Neurotoxicology 2014; 45: 209-215.

81. Wang C, Yang X, Guan J, Gao K, Li Z. Volatile organic compounds in aircraft cabin: Measurements and correlations between compounds. Building and Environment 2014; 78: 89-94.

82. Wang C, Yang X, Guan J, Li Z, Gao K. Source apportionment of volatile organic compounds (VOCs) in aircraft cabins. Building and Environment 2014; 81: 1-6.

83. Guan J, Li Z, Yang X. Net in-cabin emission rates of VOCs and contributions from outside and inside the aircraft cabin. Atmospheric Environment 2015; 111: 1-9.

84. Gao K, Xie J, Yang X. Estimation of the contribution of human skin and ozone reaction to volatile organic compounds (VOC) concentration in aircraft cabins. Building and Environment 2015; 94: 12-20. 85. Rosenberger W, Beckmann B, Wrbitzky R. Airborne aldehydes in cabin-air of commercial aircraft: Measurement by HPLC with UV absorbance detection of 2,4-dinitrophenylhydrazones. J Chromatogr B Analyt Technol Biomed Life Sci 2016; 1019: 117-127.

86. Schuchardt S, Bitsch A, Koch W, Rosenberger W. CAQ Preliminary cabin air quality measurement campaign.

2017.

https://www.easa.europa.eu/sites/default/files/dfu/EASA\%20CAQ\%20Study\%20Final\%20Report_21.0 3.2017.pdf Accessed 2017.

87. Cao Q, Xu Q, Liu W, Lin C-H, Wei D, Baughcum S, Norris S, Chen Q. In-flight monitoring of particle deposition in the environmental control systems of commercial airliners in China. Atmospheric Environment 2017; 154: 118-128.

88. Cao X, Zevitas CD, Spengler JD, Coull B, McNeely E, Jones B, Loo SM, MacNaughton P, Allen JG. The on-board carbon dioxide concentrations and ventilation performance in passenger cabins of US domestic flights. Indoor and Built Environment 2018; 28: 761-771.

89. Schuchardt S, Koch W, Rosenberger W. Cabin air quality-Quantitative comparison of volatile air contaminants at different flight phases during 177 commercial flights. Building and Environment 2019; 148: 498-507.

90. Guan J, Jia Y, Wei Z, Tian X. Temporal variations of ultrafine particle concentrations in aircraft cabin: A field study. Building and Environment 2019; 153: 118-127.

91. Liu M, Liu J, Ren J, Liu L, Chen R, Li R. Bacterial community in commercial airliner cabins in China. Int J Environ Health Res 2019: 1-12.

92. MacGregor IC, Spicer CW, Buehler SS. Concentrations of Selected Chemical Species in the Airliner Cabin Environment. Journal of ASTM International 2008; 5.

93. OEHHA. OEHHA Acute, 8-hour and Chronic Reference Exposure Level (REL) Summary. 2019.

94. WHO. WHO guidelines for indoor air quality: selected pollutants. 2010.

95. Wisthaler A, Tamas G, Wyon D, Strom-Tejsen P, Space D, Beauchamp J, Hansel A, Mark T, Weschler C. Products of Ozone-Initiated Chemistry in a Simulated Aircraft Environment. Environ. Sci. Technol. 2005; 39: 4823-4832.

96. Weschler CJ, Wisthaler A, Cowlin S, Tamás G, Strøm-Tejsen P, Hodgson AT, Destaillats H, Herrington J, Zhang J, Nazaroff WW. Ozone-Initiated Chemistry in an Occupied Simulated Aircraft Cabin. Environ. Sci. Technol. 2007; 41: 6177-6184.

97. Norgaard AW, Kudal JD, Kofoed-Sorensen V, Koponen IK, Wolkoff P. Ozone-initiated VOC and particle emissions from a cleaning agent and an air freshener: risk assessment of acute airway effects. Environ Int 2014; 68: 209-218.

98. Singer BC, Coleman BK, Destaillats H, Hodgson AT, Lunden MM, Weschler CJ, Nazaroff WW. Indoor secondary pollutants from cleaning product and air freshener use in the presence of ozone. Atmospheric Environment 2006; 40: 6696-6710.

99. Sun J. D-Limonene: Safety and Clinical Applications. Alternative Medicine Review 2007; 12: 259264.

100. Orth A-M, Lu Y, Engel K-H. Assessment of dietary exposure to flavouring substances via consumption of flavoured teas. Part 1: occurrence and contents of monoterpenes in Earl Grey teas marketed in the European Union. Food Additives \& Contaminants: Part A 2013; 30: 1701-1714.

101. Simpson S, Roux P, Dinca M. The science behind sensing and filtering cabin air. AST 2019, February 19-20, Hamburg, Germany 2019.

102. Wainman T, Zhang J, Weschler CJ, Lioy PJ. Ozone and Limonene in Indoor Air: A Source of 
Submicron Particle Exposure. Environmental Health Perspectives 2001; 108: 1139-1145.

103. Langer S, Moldanová J, Arrhenius K, Ljungström E, Ekberg L. Ultrafine particles produced by ozone/limonene reactions in indoor air under low/closed ventilation conditions. Atmospheric Environment 2008; 42: 4149-4159.

104. Rai AC, Guo B, Lin CH, Zhang J, Pei J, Chen Q. Ozone reaction with clothing and its initiated VOC emissions in an environmental chamber. Indoor Air 2014; 24: 49-58.

105. Tsushima S, Wargocki P, Tanabe S. Sensory evaluation and chemical analysis of exhaled and dermally emitted bioeffluents. Indoor Air 2018; 28: 146-163.

106. MHLW. Committee on Sick House Syndrome: Indoor Air Pollution Progress Report No. 4. 2002. http://www.nihs.go.jp/mhlw/chemical/situnai/kentoukai/rep-eng4.pdf Accessed 2002.

107. MHEPA. GB 18883-2002 indoor air quality standard. 2002.

108. AHSD. Residential indoor air quality guidelines. 2018.

109. AOLG. German Committee on Indoor Guide Values. 2018.

110. ACGIH. Risks of Hazardous Wastes. Appendix F-ACGIH Threshold Limit Value (TLV). 2011.

111. NIOSH. NIOSH pocket guide to chemical hazards. 2005.

112. Winder C, Balouet JC. The toxicity of commercial jet oils. Environmental Research 2002; 89: 0164.

113. CAA. Cabin air quality-CAA paper 2004/04. 2004.

114. Winder C, Michaelis S. Crew Effects from Toxic Exposures on Aircraft. The Handbook of Environmental Chemistry 2005; 4H: 229-248.

115. Maddalena RL, Mckone TE. Insecticide exposures on commercial aircraft A literature review and screening level assessment. Lawrence Berkeley National Laboratory 2008.

116. Denola G, Hanhela PJ, Mazurek W. Determination of tricresyl phosphate air contamination in aircraft. Ann Occup Hyg 2011; 55.

117. Howard CV, Johnson DW, Morton J, Michaelis S, Supplee D, Burdon J. Is a Cumulative Exposure to a Background Aerosol of Nanoparticles Part of the Causal Mechanism of Aerotoxic Syndrome? J Nanomed Nanosci: JNAN-139. 2018; 2018.

118. Marsillach J, Richter RJ, Kim JH, Stevens RC, MacCoss MJ, Tomazela D, Suzuki SM, Schopfer LM, Lockridge O, Furlong CE. Biomarkers of organophosphorus (OP) exposures in humans. Neurotoxicology 2011; 32: 656-660.

119. Cheng MD. Classification of Volatile Engine Particles. Aerosol and Air Quality Research 2013; 13 : 1411-1422.

120. TRGS. Technical Rules for Hazardous 2006. https://www.baua.de/DE/Angebote/Rechtstexte-und-Technische-Regeln/Regelwerk/TRGS/pdf/TRGS900.pdf? blob=publicationFile Accessed 2006.

121. Nicholson TT, Sznajder JI. Fitness to fly in patients with lung disease. Ann Am Thorac Soc 2014; 11: 1614-1622.

122. Begum E, Metin A, Grazia P, Stefano N. Should I stay or should I go? COPD and air travel. Eur Respir Rev 2018; 27.

123. Yates EL, Johnson MS, Iraci LT, Ryoo JM, Pierce RB, Cullis PD, Gore W, Ives MA, Johnson BJ, Leblanc T, Marrero JE, Sterling CW, Tanaka T. An Assessment of Ground Level and Free Tropospheric Ozone Over California and Nevada. Journal of Geophysical Research: Atmospheres 2017; 122: 1008910102 .

124. Bhangar S, Nazaroff WW. Atmospheric ozone levels encountered by commercial aircraft on transatlantic routes. ENVIRONMENTAL RESEARCH LETTERS 2013; 8.

125. WHO. WHO Air quality guidelines for particulate matter, ozone, nitrogen dioxide and sulfur dioxide. 2005.

126. Machida T, Kita K, Kondo Y, Blake D, Kawakami S, Inoue G, Ogawa T. Vertical and meridional distributions of the atmospheric $\mathrm{CO} 2$ mixing ratio between northern midlatitudes and southern subtropics. Journal of Geophysical Research 2002; 108.

127. Foucher PY, Chédin A, Armante R, Boone C, Crevoisier C, Bernath P. First carbon dioxide atmospheric vertical profiles retrieved from space observation using ACE-FTS solar occultation instrument. Atmospheric Chemistry and Physics Discussions 2010; 10: 26473-26512.

128. Tuzson B, Henne S, Brunner D, Steinbacher M, Mohn J, Buchmann B, Emmenegger L. Continuous isotopic composition measurements of tropospheric CO2 at Jungfraujoch (3580 m a.s.1.), Switzerland: real-time observation of regional pollution events. Atmospheric Chemistry and Physics 2011; 11: 16851696.

129. Sawa Y, Matsueda H, Makino Y, Inoue HY, Murayama S, Hirota M, Tsutsumi Y, Zaizen Y, Ikegami M, Okada K. Aircraft Observation of CO2, CO2 O3 and H2 over the North Pacific during the PACE-7 Campaign. Tellus B: Chemical and Physical Meteorology 2017; 56: 2-20. 
130. ANSI/ASHRAE. ANSI/ASHRAE Standard 62.1, Ventilation for Acceptable Indoor Air Quality. 2016.

131. Fisk W, Wargocki P, Zhang X. Do Indoor CO2 Levels Directly Affect Perceived Air Quality, Health, or Work Performance? ASHRAE Journal 2019; 61.

132. Du B, Tandoc MC, Mack ML, Siegel JA. Indoor CO2 concentrations and cognitive function: A critical review. Indoor Air 2020; 30: 1067-1082.

133. CEN. EN 16798-1: 2019. Energy performance of buildings-Ventilation for buildings. 2019.

134. ASTM. ASTM D6399-18. Standard guide for selecting instruments and methods for measuring air quality in aircraft cabins. Designation: D6399-18. 100 Barr Harbor Drive, PO Box C700, West Conshohocken, PA 19428-2959. United States; 2018.

135. U.S. Department of Health and Human Services, Public Health Service, Centers for Disease Control, National Institute for Occupational Safety and Health, NIOSH Manual of Analytical Methods,. 3rd edition, Vol. 1, National Technical Information Service, Springfield, VA, 1984.

136. U.S. Environmental Protection Agency. EPA Compendium of Methods for the Determination of Toxic Organic Compounds in Ambient Air: Methods TO-1 through TO-14. published from 1984 through 1988.

137. ISO 16000-6. Indoor air-Part 6: Determination of volatile organic compounds in indoor and test chamber air by active sampling on Tenax TA sorbent, thermal desorption and gas chromatography using MS/FID. 2004.

138. BS EN ISO 16017-1. Indoor, ambient and workplace air sampling and analysis of volatile organic compounds by sorbent tube thermal desorption capillary gas chromatography Part 1 Pumped sampling. 2001. 